\title{
LORDS AT THE END OF THE EMPIRE: NEGOTIATING POWER IN THE LATE BYZANTINE FRONTIERS (FOURTEENTH-FIFTEENTH CENTURIES)
}

\author{
by Fotini Kondyli \\ University of Virginia
}

\begin{abstract}
The defence of Late Byzantine (fourteenth-fifteenth centuries) frontier zones frequently became the responsibility of military elites, borderlords, who enjoyed absolute power in these areas and immunity from any fiscal or other obligation towards the Byzantine state. In this article I present the case studies of two borderlord families: the brothers and military officials Alexios and Fohn, and the Genoese family of the Gattilusi, who ruled large areas around the Northern Aegean in the fourteenth and fifteenth centuries and participated actively in their defence at a time when they were surrounded by enemies and plagued by piracy. The aim of the article is twofold. First, I consider the borderlords' building activities, modes of self-representation and the creation of new geographies as strategies for establishing control and legitimising their power. Second, I explore how the rise of these borderlords fits with Byzantine imperial policies and corresponds to changes in the character of Late Byzantine imperial authority and the role of the Byzantine emperor within and beyond the empire. Over the course of this article I hope to highlight the complexity of the political and economic situation in the fourteenth and fifteenth centuries and contribute to an understanding of modes of Late Byzantine government and power that move beyond simplistic frameworks of decline and fall.
\end{abstract}

\section{INTRODUCTION}

In the famous Byzantine epic of Digenis Akrites, a two-blood borderlord defends the empire at the Byzantine-Arab borders by the Euphrates (Hull 1972; Elizbarashvili 2010, 437-60). The name of the hero, Digenis, meaning 'two-blooded', refers to the union between his Arabturned- Christian father and Christian mother, and speaks to the religious and cultural exchange in the borders as well as to borders' permeability and fluidity (Elizbarashvili 2010, 443). His name Akrites, defender of borders, points to the political and military realities in Byzantine border zones and the role of local military elites in their protection (Stein 2007, I8-I9; for the role of the Akritai, Hull 1972, xviii-xix). Although Digenis spends more time fighting for love than actually defending the Byzantine borders, this poem 'preserves and exalts the memory of a frontier society that was vital to the empire's existence' (Magdalino I993, 438; cf. Elizbarashvili 2010). In the long eleven centuries of its existence (from the fourth to the fifteenth centuries), Byzantium was constantly engaged in warfare and witnessed dramatic changes in its borders, moving between expansion and territorial loss until the fall of Constantinople in I453. While the epic of Digenis encapsulates the political and military realities of the Middle Byzantine period (tenth-twelfth century), it highlights also Byzantine policies in border protection and territorial control that continued and were further crystallised in the Late Byzantine period. The management and defence of border regions was often entrusted to members of local elites, such as Digenis, who, having lived and acquired fortunes in those areas, had interests in their protection and well-being. The Digenis epic speaks also to a distinct frontier culture and captures key characteristics of military elite families who played an important role in the political and economic life of the borders (Haldon 1999, 244). It also serves as a commentary on the complex relation of collaboration, tension and competition between borderlords and the central administration which is a key theme in this study (Falkenhausen 1984, 21 I-35; Magdalino I984; Magdalino 1993, 5-7; Lilie 2005, I6).

This article explores the identity of borderlords in the fourteenth and fifteenth centuries and their role in in the political life of the empire, particularly the defence of Byzantine borders. It 
also considers borderlords' relationship both to the Byzantine emperors and to the local populations under their control. The case studies presented here include Byzantine and foreign elites, and raise questions about individual borderlords' ethnic, political and religious identities. How did the borderlords' different identities inform their strategies for legitimacy and rule? How did they affect the political and socio-economic conditions in border zones? The borderlords' role in the protection of the empire provides a window onto a better understanding of state mechanisms and changes in the political management of the Late Byzantine Empire. The study of Late Byzantine frontier zones through the lens of borderlords allows us to move beyond simple state-centred approaches to the formation of overlapping political landscapes and reassess state-society relations and the negotiation of power at the edges of the Byzantine Empire. It also reintroduces Byzantine frontiers as zones of overlapping networks of communication and of political and socio-economic relations.

In comparison to previous studies on Late Byzantine military elites and their participation in the defence and administration of the empire, this article places more emphasis on the material evidence. I rely primarily on archaeological and architectural evidence to explore how borderlords chose to represent their authority before different audiences and through different media. The material evidence discussed here provides a direct window onto these borderlords' decisions, political strategies and the mechanisms they employed to establish their power and increase their influence. An archaeological approach also allows for an in-depth study of the multiple meanings and the reception of the political messages embedded in the borderlords' actions, building projects and the visual language they employed.

\section{POLITICAL REALITIES IN LATE BYZANTIUM (THIRTEENTH-FIFTEENTH CENTURIES)}

The borderlords discussed in this paper, the frontier zones under their control and their relation to central authority are products of the specific political, economic and demographic conditions in the Mediterranean during the Late Byzantine period and the second half of the fourteenth century in particular. The course of the Byzantine Empire changed irreversibly with the Fourth Crusade in I204 that led to the loss of Constantinople and the majority of Byzantine territories to the Franks and Venetians (Nicol I993, I-9; Angold 1999; Angold 2003). In the aftermath of the Fourth Crusade, a series of Latin and Greek succession states gave rise to a politically fragmented Eastern Mediterranean that further contributed to the fragmentation and the decentralisation of the later Byzantine state (Laiou 2005; Necipoğlu 2009, 2I-2). When the Byzantines finally regained control of Constantinople in I26I, they found themselves in a new world in which they could no longer set the rules of the game (Laiou 2008). Western powers had established themselves in former Byzantine territories and Italian maritime powers, Venice in particular, were in control of the Mediterranean trade. In comparison, the newly reestablished Byzantine state had limited resources and exercised limited political control over a small number of territories.

The territorial losses and overall shrinkage of the empire conditioned imperial and elite power in these late centuries. Land meant resources and power for the state; it translated to an income that was used to finance the army and the fleet and as a reward system for military services and for maintaining the loyalty of the elites (Frankopan 2009, II3). Loss of lands and inability to defend its territories and maintain a serious army and fleet weakened the state, threatened its safety and created dissatisfaction and distrust among the local population and army (Necipoğlu 2009, I920; Haldon 2009, 203).

Within this framework of political turmoil and territorial loss, the Byzantine civil wars in the fourteenth century between members of the ruling family of Palaiologoi and their court were a turning point (Stathakopoulos 2009, 93). The wars devastated the empire and exhausted its finances, which led to the weakening of central authority and its control over military resources (Frankopan 2009, I20). They also led to alliances with foreign powers, such as the Serbians and Turks, and their infiltration into Byzantine territories with catastrophic results: for example, the 
first Ottoman foothold in Europe (Gallipoli) in I354 was a result of such alliances (Nicol I993, I5266, I85-208; Necipoğlu 2009, 20-I; Chrissis and Carr 20I4, II). In the aftermath of the civil wars, Byzantine emperors were forced to depend upon military and financial support from the West and in the meantime to try to appease the Ottomans (Nicol I993; Necipoğlu 2009, I8-38; Kyriakidis 20II, 37). Finally, many elite families that were engaged in the civil wars found their fortunes exhausted, their lands lost to enemies or confiscated and the foundation of their power destroyed. These conditions gave rise to new elites who could master the flux of these years both financially and politically. Many of them had little in common with the traditional elite families with long lines of titles, connections and political career in the court; Angold (I984a, 6) characterised them as 'adventurers'. It is just such adventurers who are the protagonists of the second half of the fourteenth century and of this study.

The civil wars of this era fuelled the political conflict among elites and contributed to the political fragmentation within the empire. For example, in an effort to balance and satisfy the ambitions of members of the Palaiologoi and Kantakouzenoi, John VI Kantakouzenos divided the empire and allocated large territories to each prince to rule independently in Macedonia, Thrace and the Morea (Stathakopoulos 2009, 96; Kyriakidis 20II, 35-6; Wright 20I2, 25I-2). Similarly, Thessaloniki was ruled as a semi-independent city by members of the imperial family and enjoyed significant autonomy (Necipoğlu 2009, 45-7). Centrifugal tendencies were not new in Byzantine politics: they are well attested at the end of the Middle Byzantine period and especially during the late twelfth century, when separatist movements increased and provinces started relying more upon local and regional elites (Angold 1984b, 243; Savvides 1987, I2 I; Haldon 1999, 238; Anagnostakis 2015, 136). Financial stress and the inability of the state to protect the local population and secure their interests fuelled local dissatisfaction and turned the provinces against Constantinople and towards local magnates who were ready to protect them and their interests even against the central administration (Angold I984b, 242; Savvides I987, I24-5; Anagnostakis 2015, 147-8). The power of such elites and their influence in the provinces remained strong even after 1204 and was acknowledged by the Latins. In the case of Adrianopolis, for example, the Venetians left the governance of the city in the hands of the local elites on the condition that they provided military service when needed (Angold 1984b, 244). Such centrifugal phenomena, which promoted localism and allowed elites to rule regions quasiindependently, further crystallised in the Late Byzantine period and conditioned the relationship between elites, provinces and the state. By the second half of the fourteenth century the empire had split up into a series of apanages for the members of the ruling houses, each with its own small court and princes, creating a constellation of hubs of political activity scattered in the Eastern Mediterranean. Under these conditions it is difficult to talk about an empire in the traditional sense, since there is a lack of political, administrative and even territorial cohesiveness (Kiousopoulou 20II, 6-7; Angold 1984a, 6; Necipoğlu 2009, I8-19). These multiple centres of power often became a barrier to a uniform foreign policy and prompted different and less centralised solutions to the empire's administration and defence (Necipoğlu 2009, 22).

\section{LATE BYZANTINE BORDERS AND THEIR DEFENDERS}

The study of borders, frontiers and borderlands has been a developing field among historians, social and political scientists, archaeologists and geographers. Notions of borders as linear, fixed and permanent entities go back to Turner's work on the American West frontier which has long been criticised for its inapplicability to other political conditions and environments and failure to recognise the permeability and fluidity of borders (Turner 1963; for a critical approach to Turner's work, see Slotkin 1992; Kutchen 2005; Naum 2010, I02-3). In the case of ancient and medieval states, linear and clearly defined border lines emerge in texts as part of the construction of political propaganda and imperial ideology but have little to do with the reality on the ground (Berend I999; Pohl 2005, 265; Smith, M.L. 2005; Kulikowski 2005, 247, 252-3; Parker 2006, 80). Furthermore, as Stephenson (1999, 81, 97) notes, in Byzantine textual sources 
frontiers were understood as entire regions as well as political boundaries, further challenging the notion of linear borders. The capacity of ancient and medieval states to control their borders has also been overstated; according to Byzantine historical accounts, borders were often breached despite garrisons and fortifications, even in the case of massive barriers, such as the Anastasian wall in Constantinople's hinterland (Smith, M.L. 2005; Crow 2013). Byzantine borders were associated with landmarks, such as cities and castles, rather than linear, steady and highly recognisable markers. Border control was achieved by controlling important landmarks and main routes, while open areas around these landmarks continued to be contested (Kaegi I996; Pohl 2005, 260-I; for similar phenomena in the Ottoman period see Stein 2007, I4-I5). Such definitions of borders emphasise the permeable and unstable nature of Byzantine borders and place great emphasis on the control of fortifications and fortified cities. In fact, in the fourteenth century castle sieges outnumbered all other types of military conflict, suggesting that the protection of defended sites was synonymous with the protection of the borders, especially at a time when the state had neither the resources nor the army to control large frontier areas (Kyriakidis 20II, I57-63, I84; for the role of fortifications in the borders see also Haldon I999, 249).

The protection of the Byzantine Empire and its borders, the organisation and financial support of the army and the decisions on war were the emperor's prerogative (Cheynet 2006, 37; Kyriakidis 20II, I5). Even in Late Byzantium, despite the lack of resources and the key role of elites in the defence of the empire, emperors never lost their interest and primary role in war and the empire's protection. Late Byzantine emperors continued to allocate substantial revenues towards the defence of the empire's borders, involving repairs of existing fortifications and the strengthening of the defence network by new forts, as exemplified by the building projects of Michael VIII in Asia Minor in the late thirteenth century and Andronikos III in Thrace and Macedonia in the first half of the fourteenth century (Kyriakidis 20II, I58). The empire's diminishing lands had, however, direct and serious consequences for the state and deprived it of the means to maintain an army and a fleet. They thus forced Late Byzantine emperors to 'outsource' the defence of the empire's borders to third parties, elite and non-elite, who had the resources and the armed and naval forces to protect Byzantine territories, and rely more heavily on the Italian maritime powers for help.

One of Byzantium's main policies was to grant public and imperial lands to individuals as a reward and in exchange for their services, especially military support. In this section I discuss how such policies informed the defence of the Late Byzantine borders, and I examine the three military groups who were recipients of such grants and directly involved in border protection: simple soldiers, Byzantine military officials, and foreigners with armies and fleets available for hire.

The institution of pronoia was the main way of financing the army from the eleventh century onwards and included the allocation of imperial lands to soldiers to settle and exploit in return for their military service (Kazhdan and Wharton 1985, 60-I; Cheynet 1990, 237-47; Cheynet 2006, 29; Bartusis 2013). Pronoia translated into wealth, power and prestige (Haldon 2009, I70, 195; Frankopan 2009, II3). It provided individuals and groups with access to lands and consequently with an income, accompanied by significant tax exemptions, including property tax, which increased their wealth and influence. Pronoia was also the direct marker of a special relationship between the holder and the emperor, and it thus bore social significance and power that came with proximity to the emperor (Cheynet 2006, 28-9; Frankopan 2009, 126). The importance of pronoia for a functioning army and for the defence of the empire more broadly can clearly be seen in the situation of late thirteenth-century Asia Minor as described by the Byzantine historian Pachymeres. He mentions that the soldiers of Asia Minor could not fully prepare for war and arm themselves because they had lost the properties they had held through pronoia (Pachymeres 4.285; for this incident see also Bartusis 1992, 75; Kyriakidis 2011, 78-9). The constant advances of the Turcomen in Asia Minor and the loss of territories, and therefore of pronoia, led to the dissatisfaction of soldiers and local elites in the borders, who felt that the state was able no longer protect their interests, leading many to join the enemy (Kyriakidis 20I I, 27).

Grants and privileges, particularly donations of lands in exchange for services instead of cash salaries, were also witnessed in the upper tiers of military command and government of the 
peripheries (Bartusis 2013, 599). As Neville has argued, Byzantine governors and generals in frontier zones were encouraged to live off these territories received from the emperor, being allowed to harvest and keep for themselves the revenues instead of sending the collected taxes back to the imperial treasury, pointing to a strong link between land and defence (Neville 2004, 24; see also Kazhdan and Wharton 1985, 60-2; for similar policies in the management of the Ottoman borders see Stein 2007, 133). Land grants and tax exemptions in lieu of a salary had become prominent at the end of the eleventh century and continued throughout the Late Byzantine centuries. They gave rise to a landed aristocracy which maintained substantial properties in the province supported by these grants, and allowed them to increase their wealth, power and influence (Haldon 2009, I70).

Byzantine emperors were especially interested to use these grants to harness the power of elite families located in frontier zones. As is evident in the Digenis poem, the imperial administration was looking for such elites to organise the political and military life of the borders and create buffer zones between Byzantine core areas and its enemies in both an official and unofficial capacity (Magdalino I993, 8).

A fundamental difference between the Middle and Late Byzantine periods is that it is difficult to speak about private armies and initiatives in military affairs before the thirteenth century. In the Middle Byzantine period, and especially in the Komnenian dynasty, the military achievements and prowess of Byzantine emperors were exalted. This is a period that witnessed the rise of military elites in the borders and produced a line of emperors who came from such families. Men such as the emperor Manuel I Komnenos (II43-80) relied on his family military pedigree and modelled himself upon military heroes of the frontiers, such as Digenis, to push his aggressive military policies and gain popular support for his constant campaigns in the East (Jeffreys I980, 484; Kazhdan and Wharton 1985, II5). The only exception is a short period at the end of the eleventh century when, owing to repeated invasions of the eastern borders and financial shortage, the Byzantine emperors turned to wealthy individuals and entrusted them with the restorations and building of castles (Cheynet 2006, 36). In the Late Byzantine period members of the high elite, such as John Kantakouzenos and Alexios Apokaukos, built fortifications, paid towards the salaries of the army and contributed financially to the rebuilding of an imperial fleet (Kyriakidis 20II, 33-4). Kantakouzenos' testimony of elite participation in the defence of the empire is telling, although we must take into account that such declarations in his history aim at legitimising his own actions. Still, he wrote that he never objected to elite contributions to the causes of defence and the army and he declared that he did not want to be outdone by anyone in the financial support he offered for the empire's protection (Cantacuzenus I.I85: see Schopenus 1828-32). It is important to note that while these aristocrats participated more actively and financially in matters of war and defence, they did so with imperial permission and in the hope that their financial support of military affairs would enhance their influence over the Byzantine emperor (see also Kyriakidis 20II, I6I).

Mercenaries and foreigners were also in the service of Byzantine emperors, actively participating in the defence of the empire and holding key positions in its military and political life. Early in Michael VIII's reign, the Aegean was ruled by several Latin lords and was also plagued by piracy, making the reconquest of the Aegean both a priority and a challenge, considering the lack of a fleet and the means and time to build it. The career of Licario, a Lombard adventurer, exemplifies imperial policies under Michael VIII that allowed foreigners to play a critical role in the defence of the empire. Michael recruited Licario for his knowledge, naval skill and fleet. He made Licario responsible for commanding the mercenaries and leading major naval operations aimed at re-establishing Byzantine control in the Aegean and, more importantly, bringing Negroponte under Byzantine control. In return for his services, Michael bestowed high official titles and honours and even gave him Negroponte as his fief in return for his services (Angold 20I2, 35-7). Pachymeres saw this series of unprecedented events as a 'necessity'; at a time of limited resources and no fleet, Michael harnessed the available talents of pirates, mercenaries and adventurers to create his own navy and establish Byzantine control over islands and coastal areas that were crucial for the survival of the recently re-established empire (Pachymeres 4.597: see Failler 1999). By bestowing lands and titles he also connected men like Licario to his person 
and ensured their loyalty. His grant of Phokaia to the Genoese brothers Manuel and Benedetto Zaccaria should be understood under the same premises (Miller I9II; Angold 2012, 36; Carr 20I4). Michael's practices were born of necessity and lack of resources as well as his need to establish his own authority and legitimacy. In doing so, he paved the way for later Byzantine emperors who found themselves in a similar position.

By the time Emperor John V came to the throne as sole emperor in 1354 there was no money in the imperial treasury; and with the Ottomans gaining a European stronghold and developing a stronger fleet, the need for territorial control and defence became ever more pressing (Necipoğlu 2009, 25; 43; Kyriakidis 20II, 36). Under these circumstances, John V and the emperors who followed had to turn to individuals within and outside the traditional elite groups who had the means, in terms of resources and fleets, to create a buffer zone of security around the remaining Byzantine lands. That included elites and non-elites, Byzantines and foreigners, and even religious institutions, such as the Athonite monasteries, which became more involved in defence projects after the civil wars (Kondyli 20I0; 20I6). The overlapping and often conflicting motivations and agendas of these groups meant that borders were contested areas of power not only across political boundaries but also between different political and social groups within a frontier zone (Wilson and Donnan I998, 5-6; Baud and Schendel I997, 219; Zartman 2010, 4-6).

\section{THE PROFILE OF A LATE BYZANTINE BORDERLORD}

Late Byzantine borderlords were agents of power and key contributors to political landscapes shaped by their political aspirations and strategies. I present here two case studies of borderlords in the fourteenth and fifteenth centuries, focusing on the brothers Alexios and John, who became lords of several areas in coastal Macedonia and the Northern Aegean at a time when they were surrounded by enemies and operated as frontier zones (Fig. I). I also briefly introduce the case of the Gattilusi, a Genoese family who also became rulers of Byzantine regions in the Northern Aegean and Thrace in the same period. Alexios and John were Byzantine officials with previous ties to the communities they were given to rule, whereas the Gattilusi were Genoese and of Latin faith, ruling territories with a dominant Greek-speaking and Orthodox population.

Both these families fit with Angold's description of 'adventurers', individuals who seized the opportunity in the aftermath of the civil wars and underwent transformation from 'leaders of war bands' to lords of independent territories and relatives of the Byzantine emperor (Angold I984a, 6). They both received these lands with privileges and the right to rule them in the second half of the fourteenth century, mainly owing to their military services and loyalty to John V Palaiologos. They were also connected to the Byzantine emperor through marrying into the Byzantine imperial family. In what follows I compare and contrast their political strategies, building programmes and visual language in their monuments to better understand how political landscapes were formed in the Late Byzantine frontier zones. I pay particular attention to the changes and manipulation of the natural and built environment as the borderlords' mechanisms to negotiate their authority and embody their aspirations of power and legitimacy (Smith, A. 2003, 75-7). While I discuss different parts of the Northern Aegean, where the protagonists of this article operated, I pay particular attention to the island of Thasos and its fortifications. The port at Limenas in Thasos has been the subject of extensive archaeological investigation, including its architecture, spatial layout and pottery finds. Coupled with a detailed description of the area named in John's will, the archaeological evidence offers a clear idea of Limenas' transformation in the fourteenth and fifteenth centuries. Thasos remains at the heart of this discussion also because it was controlled by both the borderlord groups discussed here in consecutive periods, allowing further comparisons between different borderlords' strategies in the same region.

Following Bourdieu's (1994, I64) idea that symbolic power can be obtained and lost and therefore stands in proportion to the recognition an agent receives from the group, I investigate ways in which these agents of power both sought and received that recognition. In taking this 


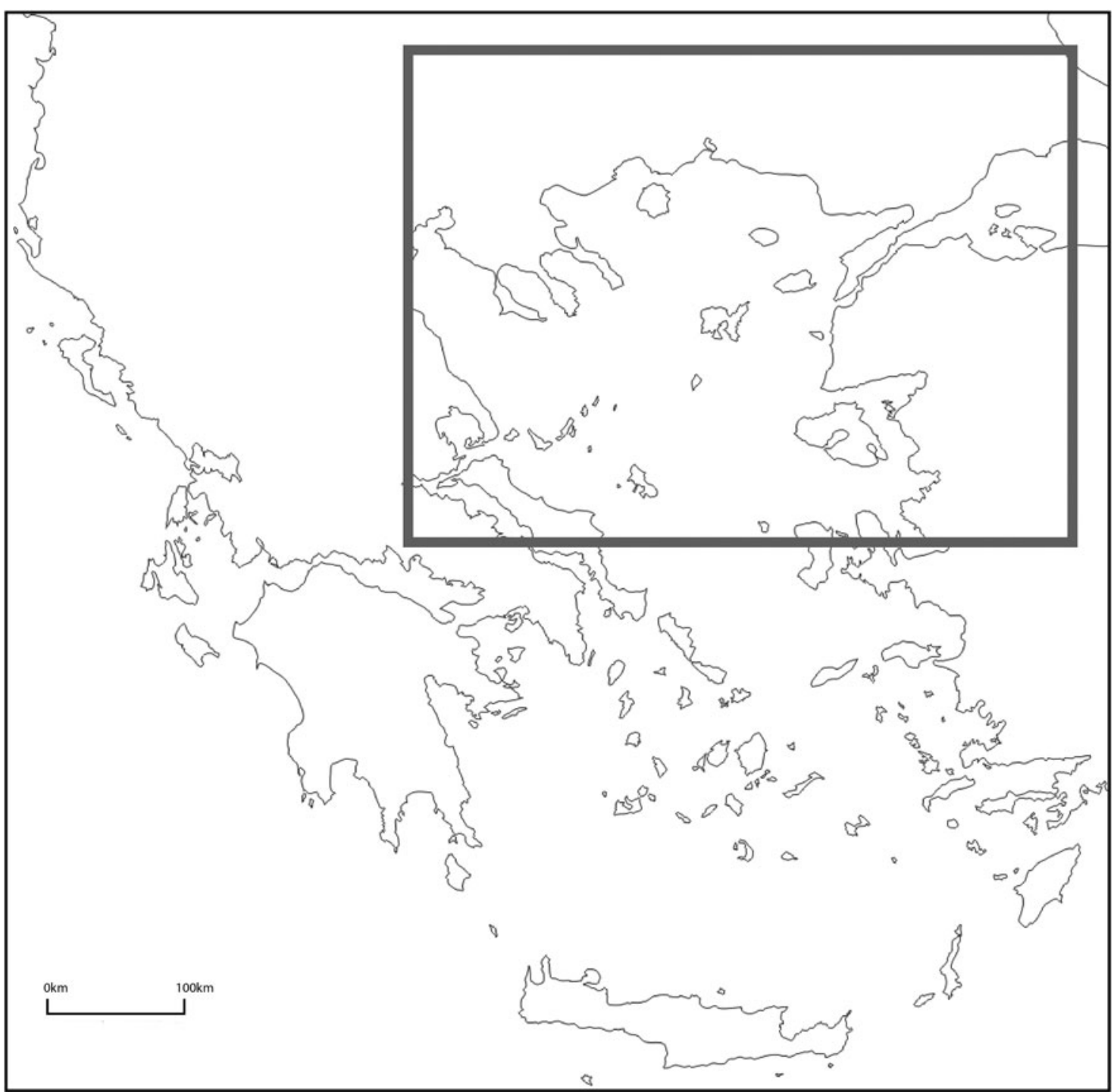

Fig. I. Area of study, North Aegean, Greece (map by author).

approach, I recognise also the other half of the political equation: the role of the ruled in promoting and challenging their rulers' authority. That is to say, in a border zone setting, local populations could support local rulers or challenge their authority through mobility and cooperation across enemy lines; consequently they had an impact upon the borderlords' strategies (Smith, A. 2003, I55-6, 228-30; Zartman 2010, 6, 9). I assess also the borderlords' cross-border networks and their relation to other political and economic groups to show how they embedded their regions in wider political and socio-economic networks, thus creating new geographies and new ties among different regions in the medieval Mediterranean. The comparative study of these two cases highlights issues of agency, authority and strategy variability in the Late Byzantine Aegean. It also underscores the impact of borderlords on the political and socio-economic realities of Late Byzantium and their role within imperial strategies of border control and sovereignty in the fourteenth and fifteenth centuries.

\section{On His Majesty's Service: The case of Alexios and John}

Alexios and John were high-ranking military officials in the service of Emperor John V Palaiologos in the second half of the fourteenth century (Kravari I99I, 7-II; Oikonomides 1996; Wright 20I4, 
89-9I). The two brothers had supported Palaiologos' claim to the throne and had proved instrumental in the defence of Macedonia, pushing back the Serbian army from the coastline. John V, in return, rewarded them with large territories from the newly freed lands in the Northern Aegean after his elevation to the throne and offered John his niece in marriage. However, it is important to also recognise that before receiving these honours and rights, John and Alexios had been conquering Byzantine territories with their own armies, acting independently from any imperial power. John $\mathrm{V}$ decided to confirm their conquests and raised them in their rank instead of going against them or demanding the territories back (Angold I984a, 6). According to the archives of the Pantokrator monastery at Mount Athos which was founded by Alexios and John, they ruled, free of any financial or other obligation, the towns of Christoupolis, Chrysoupolis, Anaktoroupolis and Limenas on the island of Thasos and also owned extensive areas along the Strymon river and on the island of Lemnos (Fig. 2) (Kravari I99I, 7-II; Eugenidou 1997, 68).

The areas under Alexios and John's control had been severely affected by the civil wars and piratical raids. The Black Death in the mid-fourteenth century had added to the areas' devastation, amplifying problems of depopulation and decreased production. Alexios and John's main priority was to create a defensive network in coastal Macedonia that would protect the local populations from future attacks and enhance surveillance and control of the sea routes that connected Thessaloniki and Constantinople. In what follows I briefly present a series of fortifications in coastal Macedonia and Thasos associated with Alexios and John's rule. For the purpose of this article I am interested in looking at these building as a way of negotiating authority and creating new political landscapes rather than discussing in depth their architectural history. Some of these castles are the result of consecutive building phases throughout the Byzantine and later periods, including expansions, additions and restorations; it can therefore be difficult to assign a rebuilding phase to the time of Alexios and John. However, it is important to note that these fortifications came under their rule, were restored and manned and participated in a new network of defence and communication created by the two borderlords.

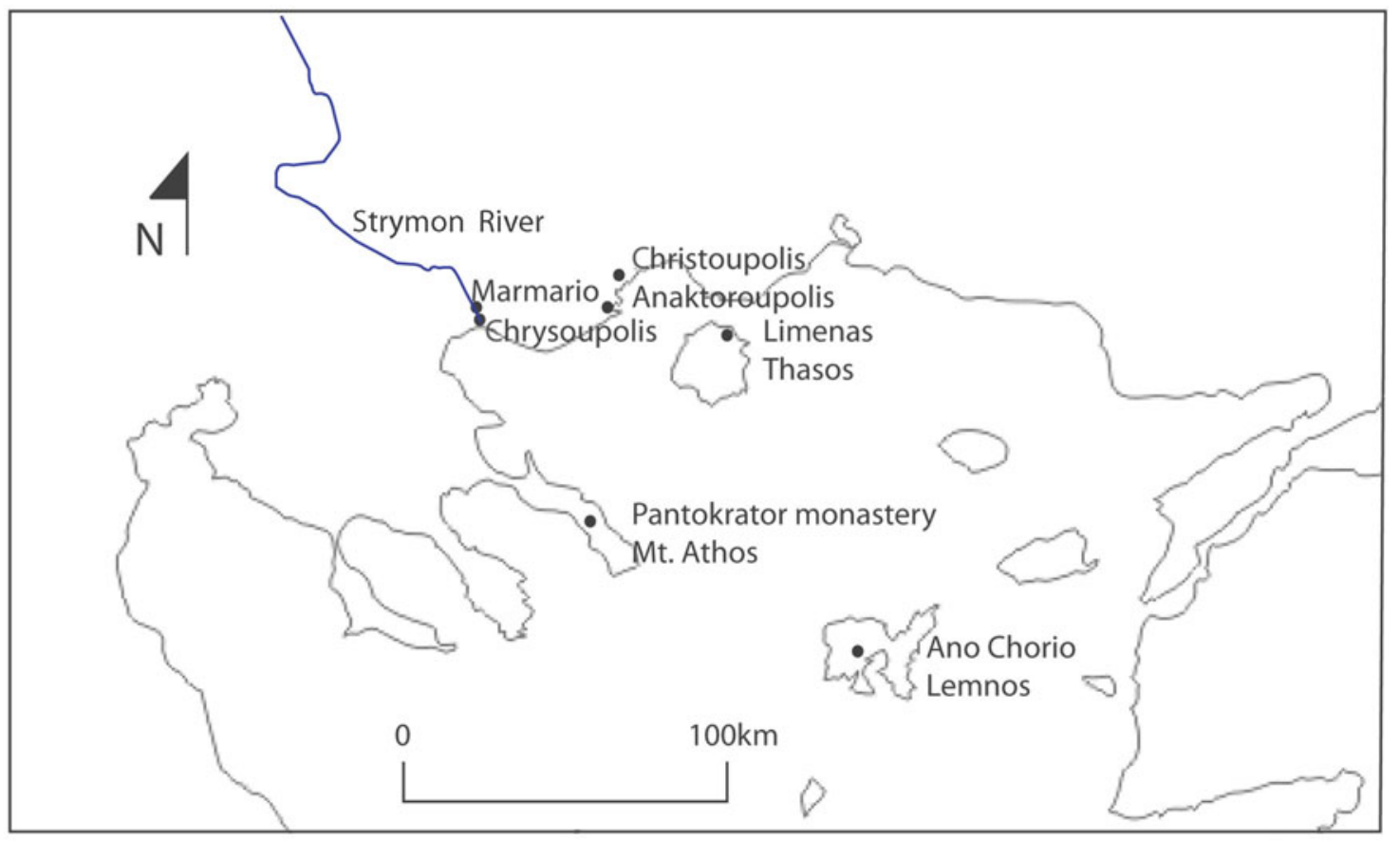

Fig. 2. Map of areas ruled by Alexios and John in the second half of the fourteenth century (map by author). 
The castle of Anaktoroupolis played an important role in the political and military events of the mid-fourteenth century. Andronikos III (1328-4I) had appreciated its strategic importance and had included it in a series of castles in Macedonia that were repaired during his rule (Karagianni, 20Io, 88-9). The coastal fortress of Anaktoroupolis functioned as Alexios and John's military base long before John V recognised their right to rule over that area. From there they fought against the Byzantine Emperor Kantakouzenos during the second civil war and even launched military attacks in nearby areas under Serbian control (Tsouris 2012, 563; Wright 2014, 89-90). The castle is an irregular rectangle built on a small peninsula with a circuit wall enclosing an area of I.5 ha, strengthened by circular, polygon and square towers (Fig. 3) (Kakouris 1980, 250; Dadaki et al. 2013, 213). It was divided into two defensive zones by an interior wall, while a lower proteichisma on the east side offered one additional line of defence. The main entrance was on the west side, flanked by square towers, while in the north-west corner remains of lower walls across the coastline could be part of a jetty (Kakouris I980, 250). The exact date of the castle's initial construction remains unknown, but literary sources point to the existence of a fortification from as early as the eleventh century (Karagianni 2010, 88, I43). An inscription discovered on the south circuit wall, together with pottery found in the debris of fallen upper walls and a contemporary coin from a nearby grave, supports a late twelfth-century date for the construction or reconstruction phase (Kakouris I980, 253-5; Eugenidou 1997, 82). It is tempting to think that some of the later repairs visible on the walls and the alterations to the towers could be associated with Alexios and John, but only a complete architectural study and extensive excavation could answer this. In any case, Alexios and John recognised and exploited the key geographical position of the castle in controlling the North Aegean Sea routes.

The castle of Christoupolis, modern Kavala, has a long architectural history, with the first defence wall dating back to antiquity, probably to the fifth century BC (Eugenidou 1997, 68). Expansions, modifications and repairs are known from the time of Justinian and again in the early tenth and late twelfth century, based on a series of inscriptions (Eugenidou 1997, 68; Dadaki et al. 2013, 214). The fortifications and part of the city were destroyed at the end of the fourteenth century, so the standing remains of the acropolis date from the first half of the fifteenth century, with later additions and alterations (Fig. 4) (Mallouchou and Tufano I980,

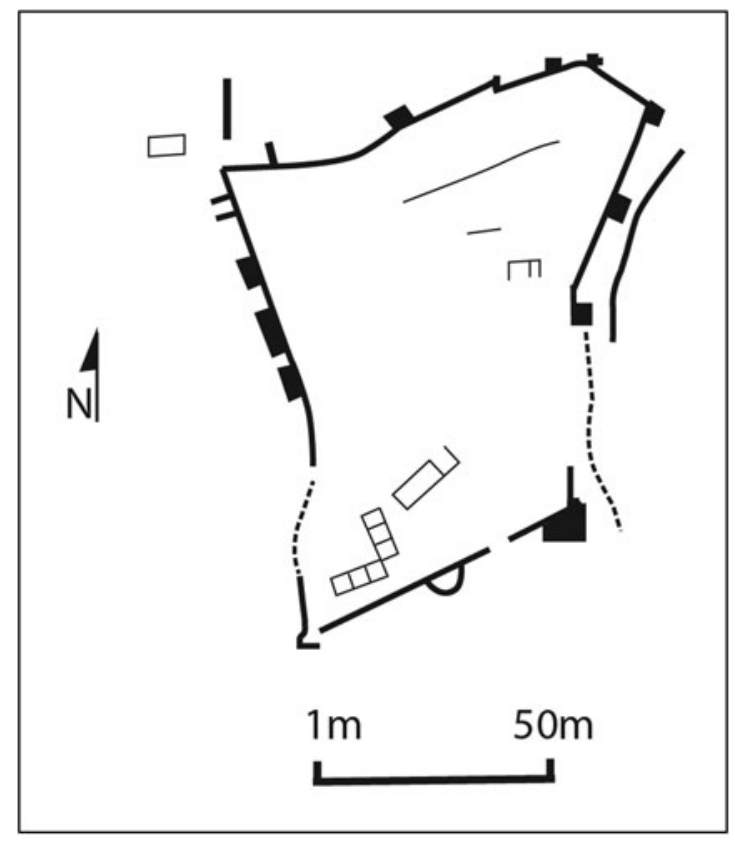

Fig. 3. Plans of the main fortifications controlled by Alexios and John at Anaktoroupolis (drawing by the author based on plan in Kakouris I980, pl. I). 


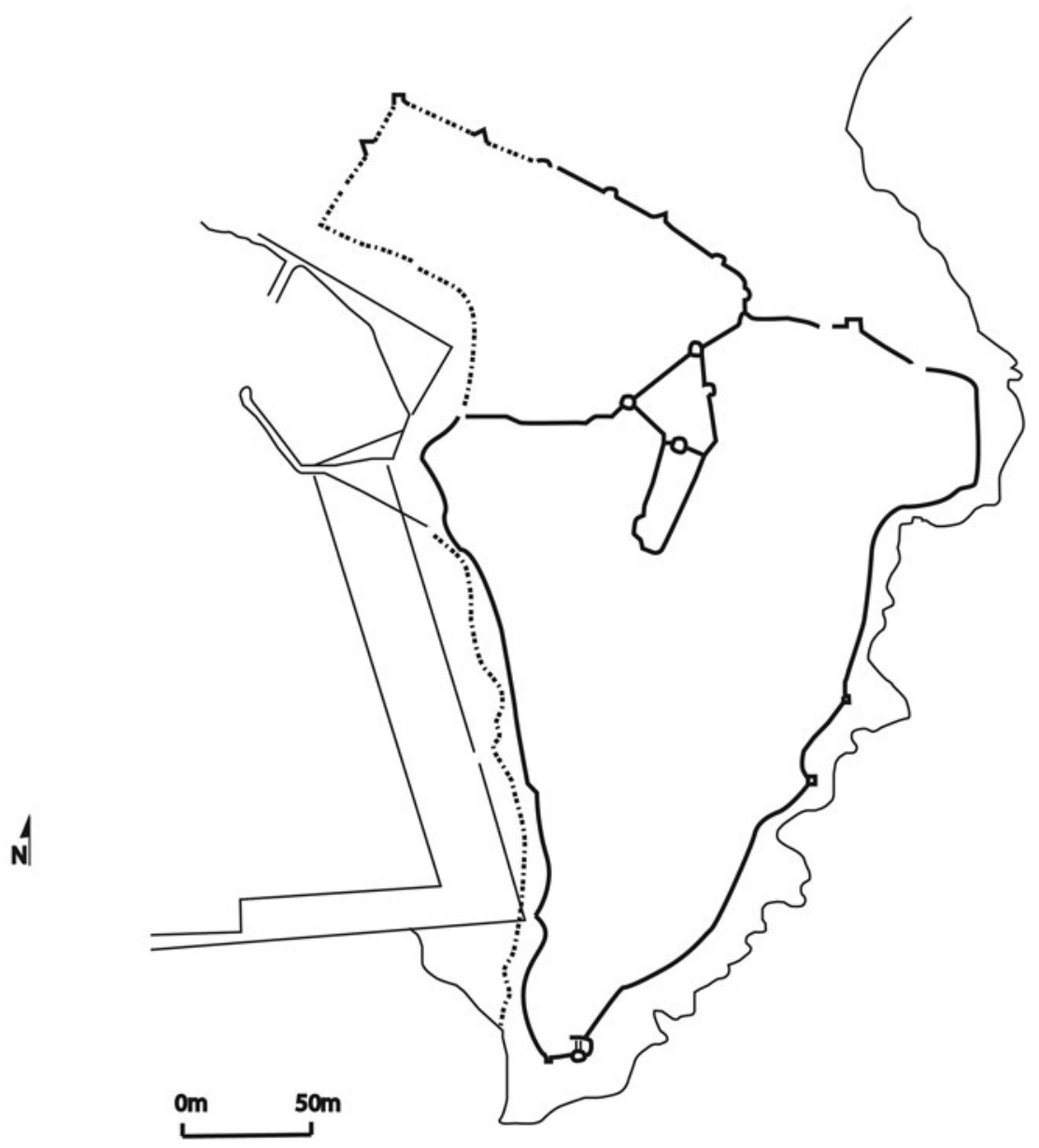

Fig. 4. Christoupolis (drawing by the author based on plan in Karagianni 2010, I39).

344-5; Karagianni 2010, I38-40). However, Byzantine features were embedded and included in the later fortifications. The central circular tower that dominates the acropolis and the nearby cistern, as well as the remains of two square towers in the outer wall could possibly be parts of the Byzantine fort (Mallouchou and Tufano 1980, 344-5). The strategic location of the castle as a connecting node between Constantinople and Thessaloniki attracted Alexios and John's interest, and they incorporated it in their coastal fortification network, probably also repairing any damage it suffered during the second civil war.

The area of Limenas and its port at Thasos were also granted to Alexios and John by Emperor John V. John, the military official, in his will emphasises the island's initial ruinous state due to piratical attacks, and refers to his successful efforts to bring order and prosperity to the island (Kravari I991, 99-100). The areas at the Limenas port excavated by the French School at Athens and the standing structures of the acropolis together reveal a strong double set of fortifications (a fortified port-acropolis) and attest to John's efforts to transform Limenas into a new economic and administrative focal point. The French excavations exposed parts of the port's defensive wall, the foundation of a tower and an adjacent well inside the fortified area matching the description of the fortifications in John's will (Kravari I99I, I00, no. IO [1384]; Giros I99I, 47; Mulliez, Muller and Blondé. 2000, 512). The port fortress was very original in 
its design, divided into at least two parts, separated by a wall and a moat, making fortifications in the shape of small islands (Fig. 5) (Spieser 1973, 542). The Late Byzantine defensive walls followed the course of the ancient Greek wall at several points and even incorporated ancient defensive architectural elements into the medieval structures, affecting the spatial organisation of the fortifications (Giros 1991, 45-50; Grandjean and Salviat 2000, 59; Mulliez, Muller and Blondé 2000, 5I4). Of the two towers found inside the defended area, the tower located at the western part of the fortress (TI in Fig. 5) was still standing in I93I, when it was demolished for the building of the new museum (Holtzmann 1979, 635-6; Grandjean and Salviat 2000, 35). It was of rectangular plan ( $14 \mathrm{~m} \times 10.6 \mathrm{~m}$ ) with a small projection on the north side where also the entrance to the tower was located (Giros I99I, 46). It was built from large blocks of spolia from the nearby ancient agora and from early Christian monuments, mortar and stones matching the appearance of the circuit wall (Giros I99I, 46). On the east part of the fortified port, the excavators revealed a bridge deck attached to another tower ( $\mathrm{T} 2$ in Fig. 5) that allowed communication between the west and the east parts (Mulliez, Muller and Blondé 2000, 5I3). North-west of the port, built upon the ancient acropolis, there is another fort overseeing the port and its fortifications, probably what John referred to in his will as 'Epano Kastro' (Upper Castle) (Kravari I99I, I00, no I0 [1384]). This acropolis, mentioned already at the beginning of the fourteenth century, might have been restored during the Latin conquest, and then again by John and Alexios before it was rebuilt and strengthened by the Gattilusi in the fifteenth century (Lazaridis 1958, 3I; Giros I99I, 45; Koder 1998, 222; Grandjean and Salviat 2000, 35; Giros and Dadaki 200I, 5I9).

A viewshed analysis (which can calculate and visualise all visible areas from an observation point, taking into consideration the topography, terrain and elevation of the observation point) was applied to Limenas' new fortifications to better understand their role in a local and regional

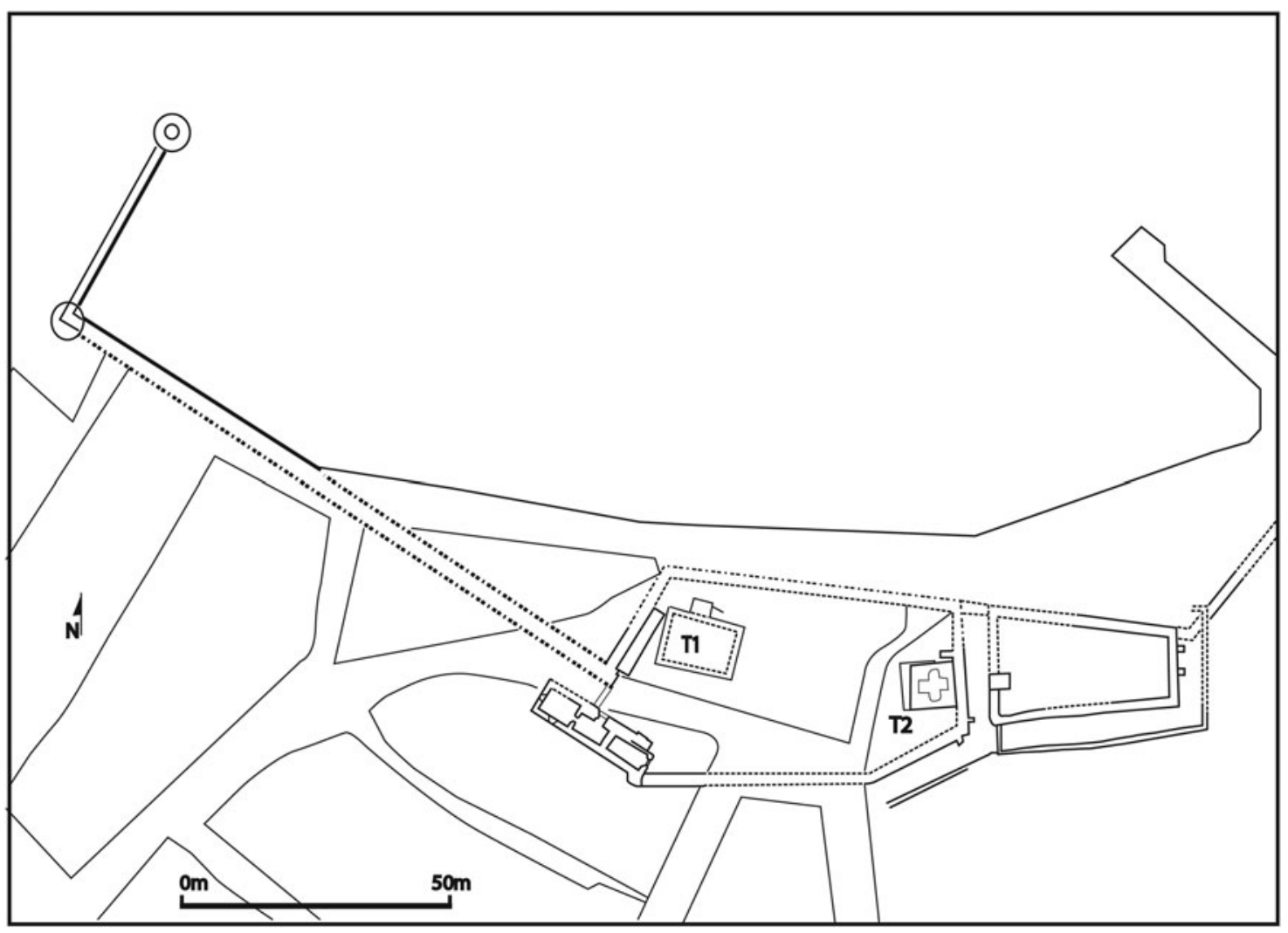

Fig. 5. Limenas, Thasos (drawing by the author based on plan in Grandjean and Salviat 2000, 513). 
defence network and thus appreciate the efforts of Alexios and John in the area. The massive mountainous centre of the island prohibits visual communication between the island's fortifications, limiting the extent of their visual control in nearby areas. In the distribution map of Late Byzantine fortifications in the island, the shaded areas indicate the extent of each fortification's visual control (Fig. 6). It becomes clear that, with the exception of Limenas, all other fortifications are located towards the interior of the island, in naturally protected locations mainly at the centre and south part of the island, and have very limited visibility and visual communication with each other. Hence, at a local level Limenas addresses the lack of protection in the north part of the island, particularly in the flat and arable plain to its east, and provides a spacious and well-protected harbour. At the supraregional level, however, Limenas participates in a wider network of defence across the sea, involving also the coasts of Macedonia. The viewshed analysis supports the possibility that Limenas had visual contact with Christoupolis, which was also under Alexios and John's control and could easily communicate with the fortifications on the opposite coast (Fig. 7). The viewshed analysis further supports the idea that the three forts of Christoupolis, Anaktoroupolis and Limenas created a triangle of communication and control operating between the mainland (coastal Macedonia) and the island (Thasos). At a local level, each castle protected the nearby resources and the local population but, at a supraregional level, they participated in a wider network of surveillance and protection of coastal Macedonia and the northern sea routes towards Constantinople.

Besides those coastal fortifications, Alexios and John also controlled areas along the Strymon river delta, including the fortified town of Chrysoupolis and the tower at Amphipolis and its surrounding area. The River Strymon provided the southern Balkans and inland Macedonia with access to the Aegean and was thus a natural focal point of communications, exchange and

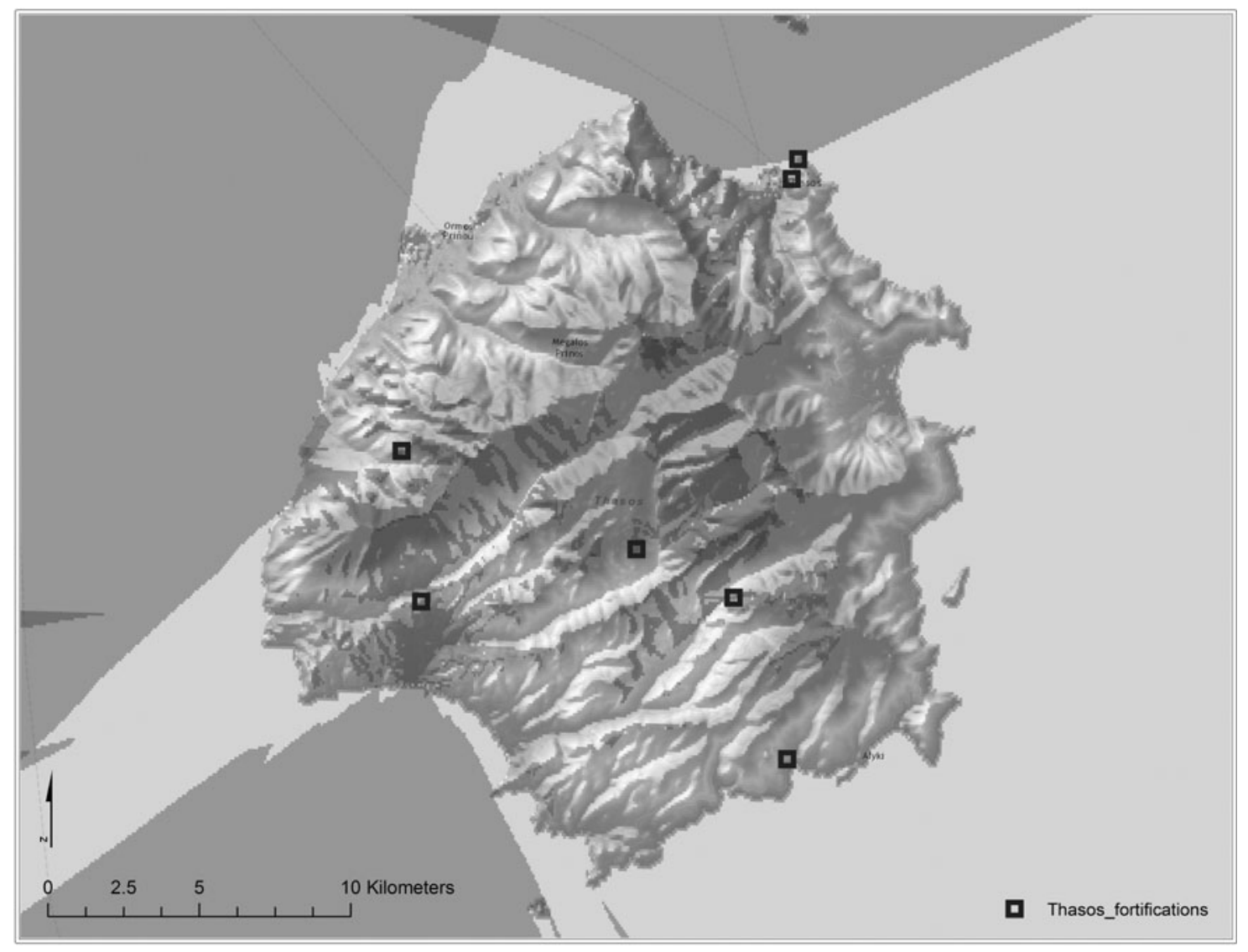

Fig. 6. Distribution map of Thasos' fortifications. Areas visible from each fortification are marked by a darker tone based on a GIS viewshed analysis (map by author). 


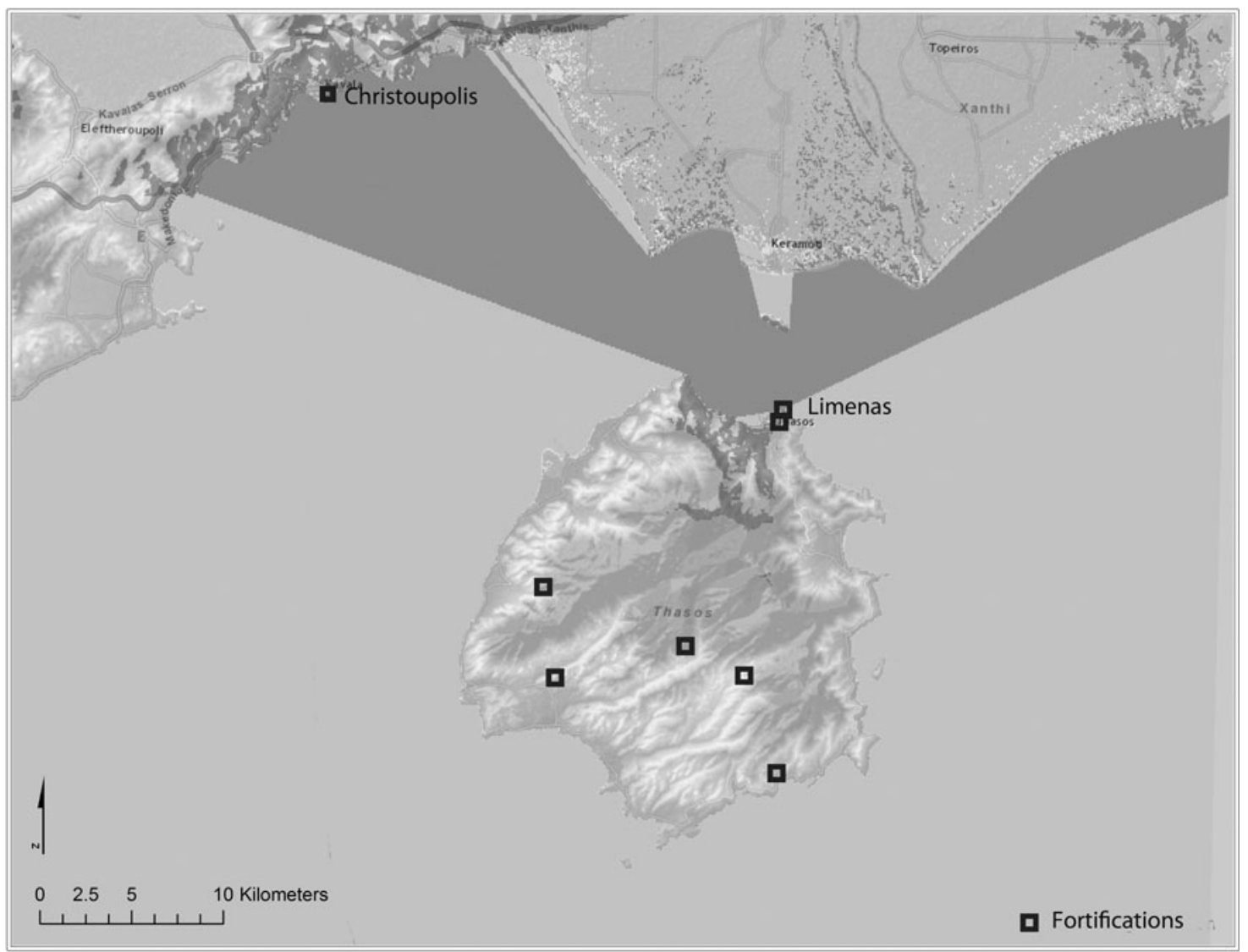

Fig. 7. Visual communication between Limenas and Christoupolis based on GIS viewshed analysis (map by author).

redistribution (Dunn 1999, 399). Owing to its strategic location, Chrysoupolis attracted the interest of the Palaiologan emperors and became an important administrative and economic centre in the Late Byzantine period. Specifically, during the reign of Andronikos III, the fortifications of the town were strengthened and expanded to the east to include an area of 9 ha (Eugenidou 1997, 86; Dunn 1999, 407; Karagianni 2010, I4I). The fort is made from two circuit walls extending east and west with a small acropolis in the middle, strengthened by square towers in the east and south side of the walls and probably by a moat on the west (Fig. 8) (Eugenidou 1997, 86; Dunn 1999, 408, fig. 4). It is unknown whether Alexios and John repaired the castle when it came under their control, but it was essential for their political and economic vision that the castle remained functional and able to provide protection to the area; the latter had been prey to enemy and pirate attacks for so long that, despite its advantageous location, it would remain uninhabited unless Alexios and John could provide sufficient protection and convince the local population not to abandon it. Furthermore, the two brothers owned vast lands in and around Chrysoupolis, as well as fisheries and mills in the north-western part of the delta, another incentive to invest in the protection of the area (Kravari I99I, 7-II, 9I-4, no. 9 [1374]; Dunn 1999, 407, 4I2).

The ancient town of Amphipolis, located north-west from Chrysoupolis by the Strymon river, was uninhabited in the Late Byzantine period, but the general area maintained its economic importance (Eugenidou I997, 86). Numerous Athonite monasteries as well as other big landowners maintained economic bases and estates in that area and even erected their own towers (Eugenidou 1997, 89-9I; Dunn 1999, 4II-I2). Alexios and John built a tower in the location of Marmario in the north-west part of the Strymon delta by the north riverbank to better control the north part of the river, to facilitate tax collection and storing of goods, and to 


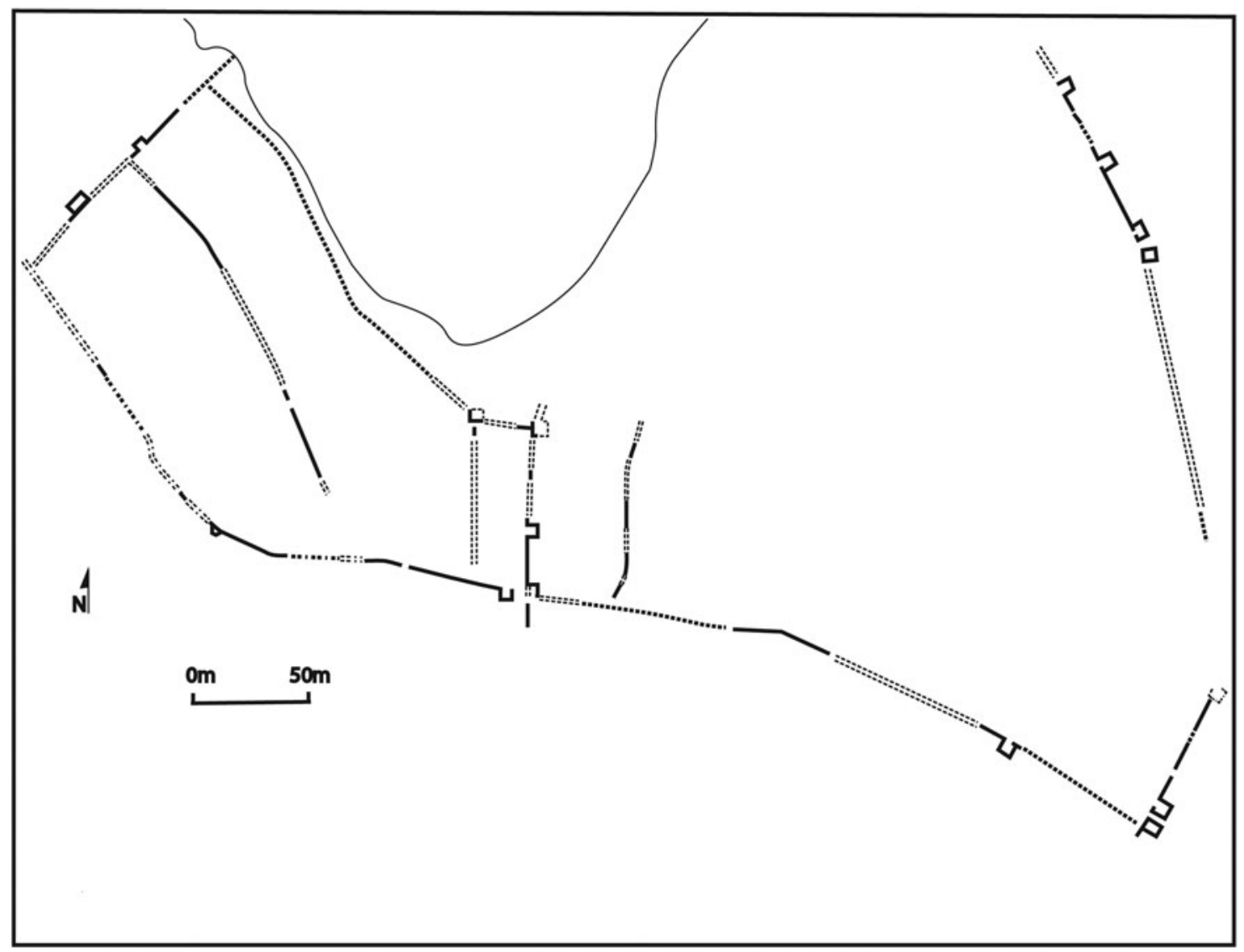

Fig. 8. Chrysoupolis (drawing by the author based on plan in Dunn I999, fig. 4, 408).

provide a visible marker of their presence in the area (Fig. 9) (Dunn I999, 4II). Its proximity to the fortification of Chrysoupolis allowed the two areas to work together in controlling movement of people and commodities in the Strymon river and its access to the North Aegean Sea.

The tower at Marmario and the fortified town of Chrysoupolis controlled a north-south corridor that leads to the North Aegean Sea, whereas the three castles of Limenas, Anaktoroupolis and Christoupolis controlled a west-east corridor in the Northern Aegean. These two sets of fortifications could very well communicate with each other, since the distance from Chrysoupolis to Anaktoroupolis can be covered in a day's journey. Moreover, free-standing towers dotted across the Macedonian coastline could become an additional link between the two sets of fortifications, allowing further communication. The Late Byzantine tower of Apollonia, for example, located between Chrysoupolis and Anaktoroupolis, could have functioned in such a way, although Nikos Zekos has recently proposed that the tower was privately owned (Zekos 2006, 57-67); even in that case, the possibility of collaboration and exchange of information among coastal fortifications in time of danger is still possible (Eugenidou 1997, 85). The tower stands in the middle of a rectangular wall enclosure, and had three storeys (with built interior staircase still visible today) and an entrance on its north side standing much higher than the ground for extra security (Karagianni 2010, I30). Its elevated position and proximity to the sea allows great command of the Northern Aegean; thus the tower could potentially participate in the surveillance of the Macedonian coastline.

This defensive network speaks volumes about Alexios and John's building activities and political strategies. The two brothers concentrated their efforts in rebuilding and strengthening the fortifications in coastal Macedonia and along the River Strymon. In doing so, they introduced a new geopolitical order, shaped by new focal points and by new connections among regions that 


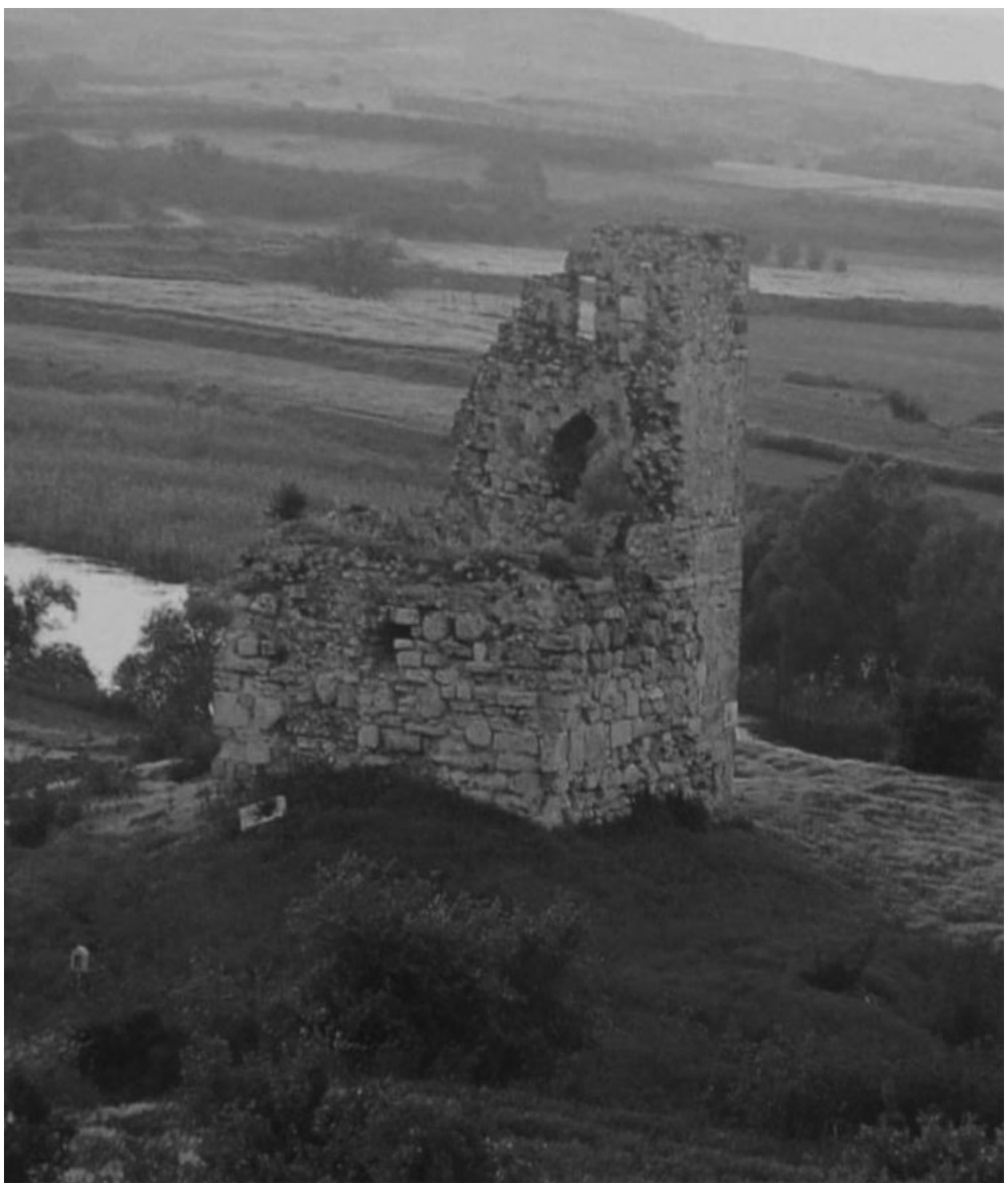

Fig. 9. Alexios and John's tower at Marmario (reprinted with the permission of both D. Eugenidou and the photographer [V. Voutsas] from Eugenidou, I997, 9I).

were now united under the two lords' control. Together with their small fleet, Alexios and John's fortifications could sufficiently protect local populations in these areas, provide safe access and control of important sea and river trade routes and offer political and economic stability in the Northern Aegean. The protection of ports, trade routes and markets points to their preoccupation with stimulating trade and other economic activities. The fourteenth-century pottery found in the excavation of Limenas imported from Macedonia, Lemnos and the capital underscores the economic interaction among these areas and points to the role of Thasos in sea commerce due to its new safe harbour (François I995, I25-30).

With their building programme, Alexios and John were addressing people in all social tiers, both friends and foes, trying to negotiate their permanent presence in the borders, emphasising their invested interests in coastal Macedonia and reminding everyone of the resources they were allocating for its protection. Through their building programme the two brothers presented themselves as powerful lords who could protect those territories and provide them with stability and prosperity. Their foundation of the Pantokrator monastery at Mount Athos enhanced their 
image as generous, wealthy and pious lords and promoted their privileged relation with God. Indicative of the way they presented themselves is the fourteenth-century icon of Pantokrator that Alexios and John donated to their monastery, now at the State Hermitage Museum, St Petersburg (Figs IO-II). Although the two brothers are portrayed as tiny figures kneeling in a gesture of deesis (prayer) at the borders of the icon (only John's portrait survives), everything about the composition speaks of their wealth, rank and social status. Both their names and titles mentioned in red letters on top of each figure and John's luxurious garments allude to their class and wealth (Fig. II). John is wearing a green caftan-like garment made of expensive material embroidered with golden thread, typical of Late Byzantine officials and aristocrats (Parani 2003, 58-6I). It is adorned with double-headed eagles enclosed in medallions, a symbol of authority, also used by the ruling family of the Palaiologoi and their relatives (Parani 2003, 58-9, 62, 335, Appendix 3, nos 43, 66, pl. 72; for the symbolism of the double-headed eagle, Androudis 2002, 16-27). His red and gold hat, known as a skaranikon, was adorned with the images of an enthroned emperor and signified John's rank, title and connection to the emperor (Parani 2007, I08; Macrides, Munitiz and Angelov 2013, 332-6).

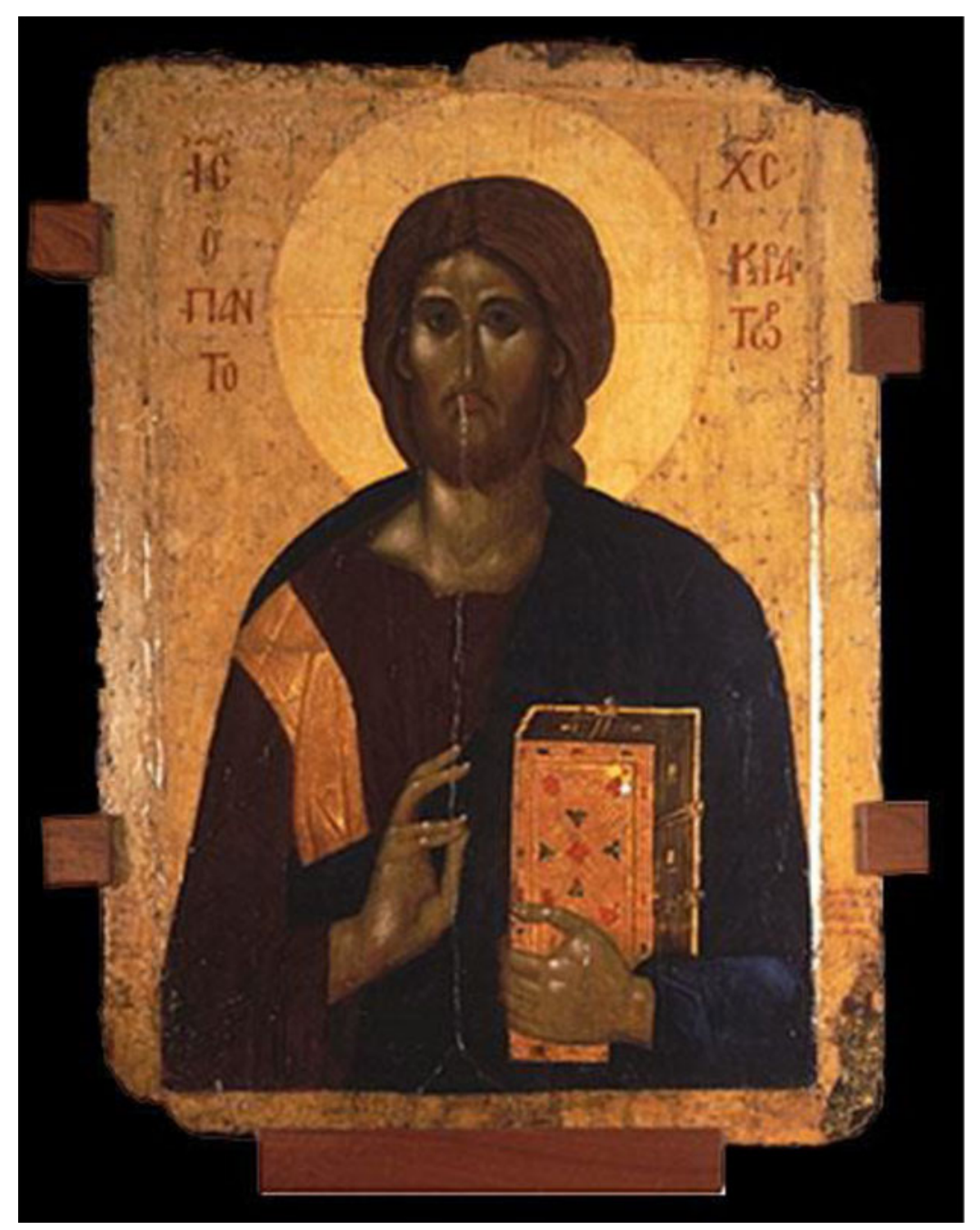

Fig. IO. Icon with Christ Pantocrator and donors. Byzantium, Constantinople artist, c.1363. Wood (lime) panel with raised borders, gesso, mixed techniques. I06 $\times 79 \times 268 \mathrm{~cm}$. Inv. no. I-515. Courtesy of The State Hermitage Museum, St Petersburg. 


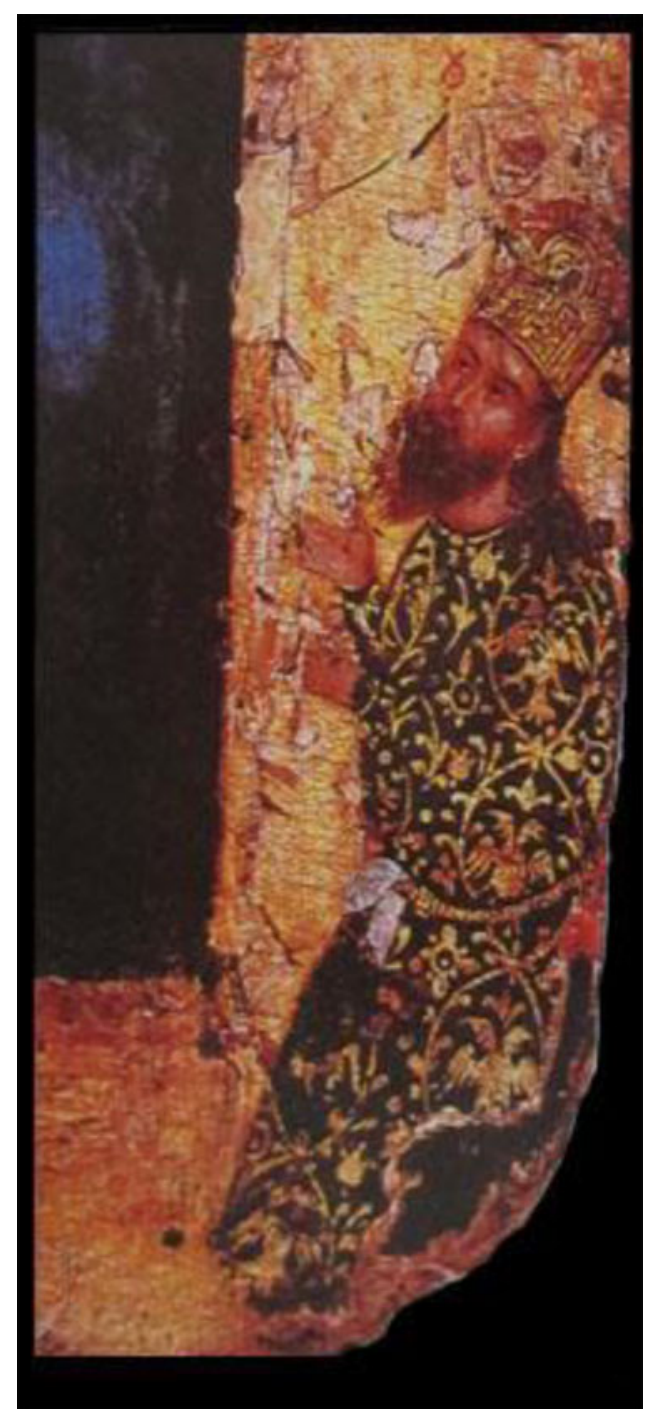

Fig. II. Detail from Icon with Christ Pantocrator and donors. Right margin showing John in prayer. Courtesy of The State Hermitage Museum, St Petersburg.

In this icon it becomes clear that Alexios and John wished to draw attention not only to their rank and status but also to their special relation to both the emperor and Christ. The references to the ruling family of the Palaiologoi in John's ceremonial costume and the skaranikon emphasise the source of his authority and his proximity to the person of the emperor. His portrait functioned as a visual reminder of the brothers' ties to the emperor and the imperial validation and recognition of the rights and property of the Pantokrator monastery. Parani (2007, I25-6) adds another dimension to portraits with ceremonial ritual garments, suggesting that such traditional court garments emphasised a diachronic and traditional Byzantine collective identity, especially at a time when foreign, Ottoman and Italian fashion was influencing Byzantine elite dress. Such a traditional Byzantine look would resonate with the two brothers' military efforts to push away enemy attacks and restore order to the Byzantine borders.

The relation with Christ is also exalted in this icon. Following a typical visual vocabulary of patronage, John appears as a tiny figure in the icon's frame, kneeling and praying (Sevcenko 1993; Carr 2006). The presence of Christ Pantokrator connects John and Alexios to the Pantokrator monastery, and both captures and perpetuates the act of donation. It highlights Christ as the source of their power and points to the privileged relation between Christ and the 
two brothers, since he is receptive of their prayer. This triple emphasis on rank, connection to emperor and Christ is a vehicle of self-representation fitting for elite patrons of an important Athonite monastery. We should not forget that the audience of such an icon were not isolated, ignorant monks: many monks in Athonite foundations were themselves members of the elite, highly connected to the Byzantine and other medieval courts, so the message of this icon is neither one-dimensional nor simply focused on religious piety.

The dedicatory inscription found in Alexios and John's tower at Amphipolis provides further evidence for the self-representation of the two brothers in the areas under their control. While their names, social status and activities are mentioned, there is no reference to the emperor or to their relation to the imperial family (Eugenidou 1997, 9I). Here the two brothers present themselves as the founders of the Pantokrator monastery and sponsors of the tower, thus placing emphasis on their own actions and wealth to negotiate their authority and not on their connection to the emperor. I think that the message here has slightly changed because the audience is different. The tower was a visual marker of the two brothers' ownership, economic activities and control of that territory, seen daily by the local population. The absence of the emperor here might be an effort by the two brothers to separate themselves from fiscal and military policies pursued by the Byzantine state, mainly the increase of taxes and inability to protect the borders. Considering that taxation under Ottoman rule in Macedonia and Thrace was significantly lower than under Byzantine rule, it is not surprising that border areas showed little or no resistance to the enemy (Frankopan 2009, I20; Kyriakidis 20II, 43). It should be equally unsurprising that the connection to the Byzantine emperor was not advertised in the tower of Amphipolis.

Their military campaigns, building programme and self-representation through artistic means and inscriptions illuminate Alexios and John's strategies of negotiating their authority and articulating their role in coastal Macedonia. In these strategies, the connection to the emperor could be emphasised or underplayed depending on the audience. In contrast, the imperial connection is highlighted in official correspondence between Alexios, John and the imperial court and in official documents, including acts of donation and selling and buying contracts. For example, in all of their official documents that have survived in the archives of Pantokrator monastery, there is great emphasis on the connection and family ties of the two brothers with the emperor, where they are always referred to as the emperor's relatives and loyal servants (Kravari I99I, 79-8I, no. 5 [1357]; 85-8, no. 7 [1368]; 88-90, no. 8 [1369]; 95-102, no Io [1384]). Alexios and John's self-presentation in different contexts supports the idea that the two brothers presented themselves in a different light when they were addressing local communities and when they were addressing the imperial court and the emperor. The absence or presence of the emperor in their rhetoric is indicative of the two brothers' interaction with the emperor. They used the imperial institutions and the imperial office in validating official documents, in dealing with bureaucracy and getting tax exemptions. But in their role as governors of coastal Macedonia and Thasos, Alexios and John relied primarily on their own efforts, military forces and wealth. Even when they were in need of military and financial support, they turned elsewhere. In their efforts to protect the Northern Aegean from piratical attacks, they sought Venice's help in 1373 and joined forces with a small Venetian fleet to protect Mount Athos from Turkish pirates (Kravari I99I, 9). After that experience, John also became a Venetian citizen, following the example of other Byzantine elites and high court officials (Kravari 1991, 9; Harris 20I2, I28-9). The two brothers' complex relations with Byzantine imperial authority and with other foreign powers, such as Venice, is further highlighted in John's will (Kravari I99I, 99-I00, no. IO [1384]). John distrusted the military and economic ability of the state to defend its borders successfully. The foundation of the Pantokrator monastery and John's Venetian citizenship were connected to his efforts to find alternative networks of support that could protect him, his assets and the local population in the areas under his control more successfully than the Byzantine emperor. At the end of his life, he donated all of his and Alexios' possessions to their own monastery, including the fortifications. John clearly thought that the Pantokrator monastery was better equipped to maintain control and protect the local population than the Byzantine state (for Late Byzantine investment in Mount Athos, see Pavlikianov 200I, 197). 


\section{Knowing your audience: the case of the Gattilusi}

Like Alexios and John, Francesco I Gattilusio had supported John V in his elevation to the throne during the second civil war. In recognition of his military services, Francesco was married to the emperor's sister, Maria, and received the island of Mytilene and the area of Ainos in Thrace as dowry (Hasluck 1908, 252-3; Wright 2012, 25I-2; Wright 2014, 78-9). Between the midfourteenth and mid-fifteenth century, the Genoese family of Gattilusio, who had started as merchants and pirates, married into the Byzantine imperial family and gradually became rulers of significant parts of the Northern Aegean, including the Thracian coastal town of Ainos, Old Phokaia, Mytilene, Samothrace, Thasos and Lemnos (Fig. I2).

The rule of the Gattilusi has recently been the subject of extensive research (Wright 2012; Wright 20I4), and thus my discussion here is brief. The case of the Gattilusi serves here as a comparison to Alexios and John's policies and allows a broader understanding of the political agendas of Late Byzantine borderlords and their material manifestation in the fourteenth and fifteenth centuries. In the comparison between the Gattilusi and Alexios and John, I am more interested in the variety of visual means the Gattilusi employed to self-represent and establish their authority in the area under their control and in the articulation of their relationship with the Byzantine emperor.

In becoming ruler of Mytilene, Francesco I Gattilusio recognised that an imperial grant alone was not enough to successfully negotiate his authority and win the trust and loyalty of the local population. The first half of the fourteenth century had been marked by a series of failures of Latin lords to successfully negotiate their authority in the Aegean, leading to riots and violent conflicts with local populations (Wright 20I2, 253-4). The generally negative atmosphere against Latins, and the resistance to Latin authority by local populations, pointed to the need for a different strategy. The Gattilusi focused on making strong connections with people under their rule, respecting their traditions, cultural values, political affiliations and history. They attempted to connect with the local population and create a shared narrative by emphasising their connections to the Byzantine court and articulating their own membership in the Byzantine Empire (Wright 2012, 248). For example, they relied heavily on Byzantine imperial iconography as a vehicle of political promotion and a constant reminder of their ties to the imperial family (Hasluck 1908, 265-6; Ousterhout 2013, 93-4). The founder's inscription dated 1373 in the Middle Gate of the Mytilene castle displays the insignia of the Palaiologoi (ПA) surrounded by the Gattilusi coats of arms on each side (consisting of scales patterns and a crowned eagle walking to the right) (Fig. 13) (Acheilara 1999, 22, fig. 22). This coexistence of the Gatillusi's coats of arms with Palaiologan insignia, such as the cross beta (four betas arranged around a

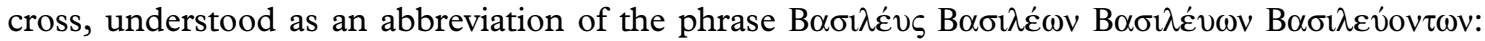
'King of Kings Ruler of Rulers'), can also be seen in the main tower in the Great Enclosure in the castle of Mytilene and in some of the Gattilusi's sarcophagi (Hasluck 1908, 263-4; Acheilara 1999, fig. 15). This visual vocabulary of power that connected the Gattilusian rule with the Byzantine emperor also extended to Gattilusian coins (Grierson 1982, 283; Bellinger and Grierson 1999, 88; Wright 2012, 248-9; Androudis 2002, 27-30). For example, some of Francesco's coins display on the obverse Palaiologan insignia, such as the cross with the four betas, and the Gattilusi's own coats of arms on the reverse (Schlumberger 1954, 437; Lunardi I980, 247). Drawing an analogy from a typical Palaiologan coin with the emperor on one side and Christ on the other as a visual reminder of the source of the Byzantine emperor's power, the Gattilusi coins can be understood as a strong political statement about the Byzantine emperor as the source of the Gattilusi's power.

Wright argues that the Gattilusian visual vocabulary of power further evolves from the I420s onwards, when insignia of Palaiologan and Gattilusian authority did not just stand side by side but were now combined to create new symbols of power; this also corresponds to the appearance of compound names (Palaiologos-Gattilusio) that started being used in inscriptions in the same period (Wright 2012, 249-50). For example, one plaque embedded in the Mytilene castle wall shows a double-headed eagle and the four betas (all symbols associated with the Palaiologoi), but on the eagle's chest one can see engraved the coats of arms of the Gattilusi, creating hybrid new symbols (Fig. I4) (Wright 2012, 249-50). A similar combination of insignia 


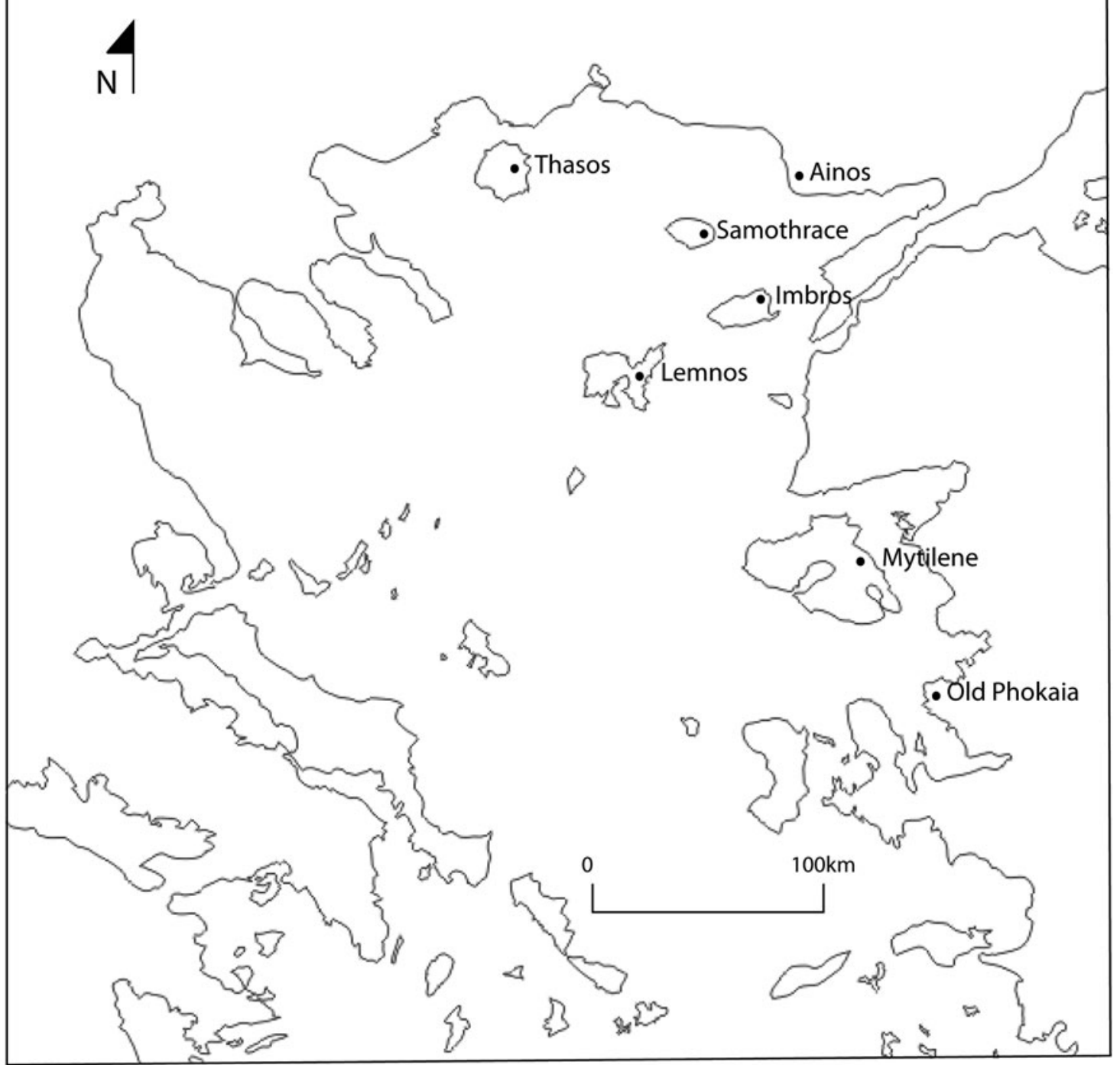

Fig. I2. Map of areas ruled by the Gattilusi in the fourteenth and fifteenth centuries (map by author).

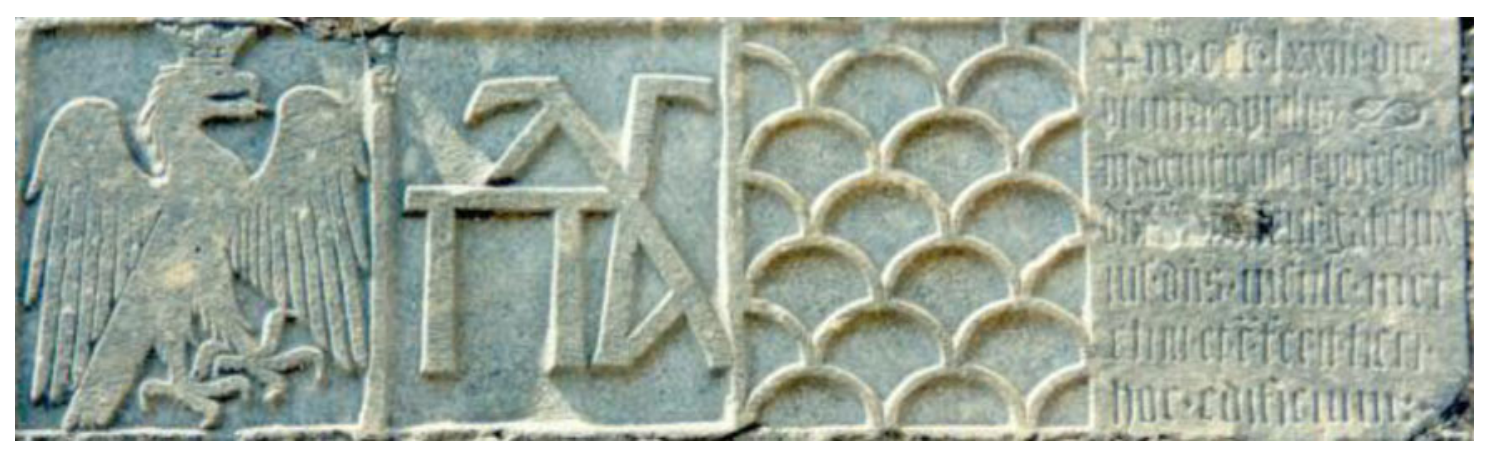

Fig. 13. Founders' inscription at the gate of the castle of Mytilene with the Palaiologan initials (ПА) and the Gattilusi coats of arms (scales patterns and crowned eagle walking to the right) (reproduced, with the author's permission, from Androudis forthcoming). 


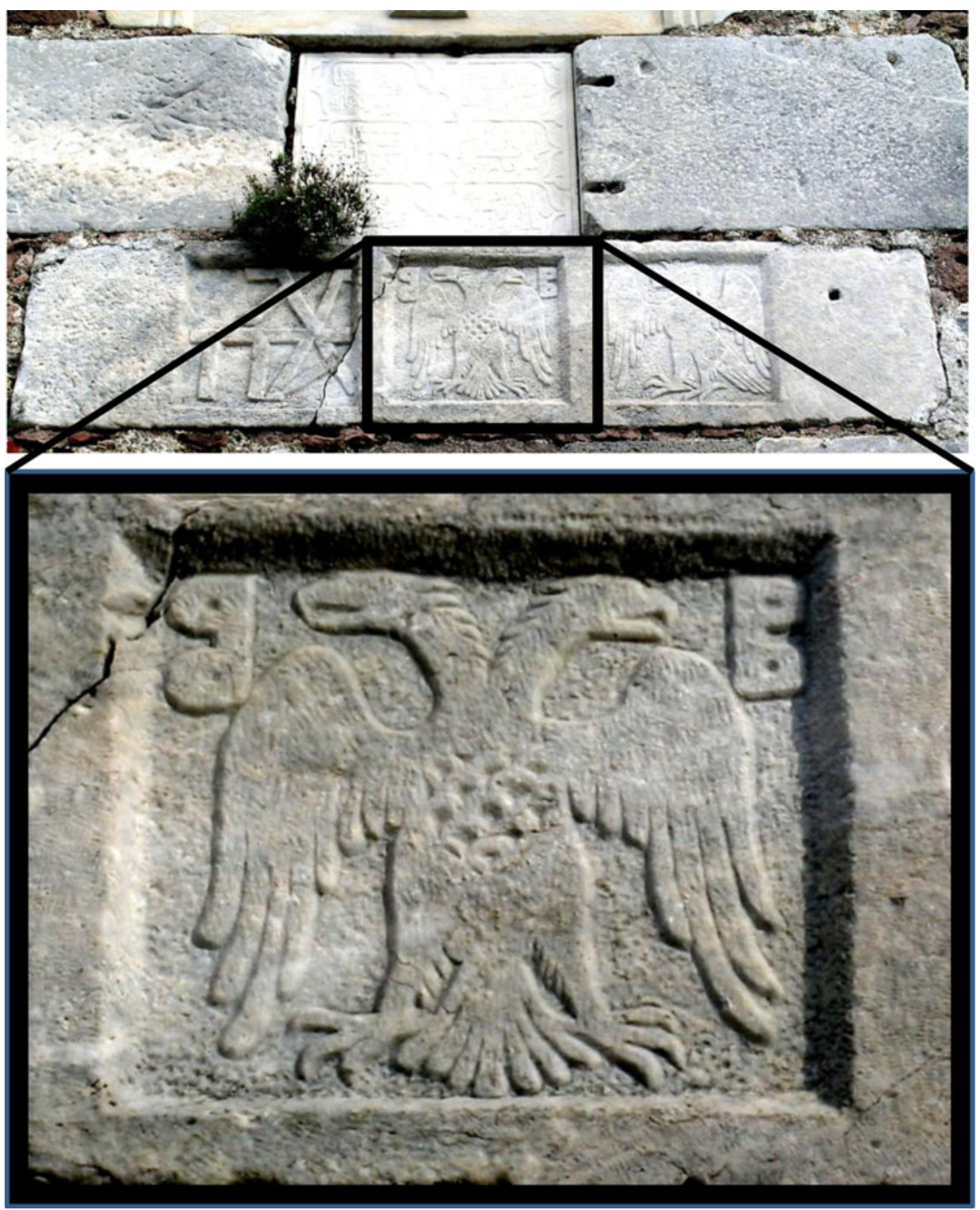

Fig. I4. Marble block with three panels containing the Palaiologan initials, a double-headed eagle with the Gattilusi coats of arms in his chest and an eagle walking to the left, Mytilene castle (reproduced, with the author's permission, from Androudis forthcoming).

can be found on the coastal fortification walls of Old Phocea, also under Gattulusian control (Hasluck 1908, 257-8; Androudis 2002, 26). A marble slab later embedded in a house's facade includes three panels with the monogram of the Palaiologoi, a double-headed eagle bearing an escutcheon with the Gattilusi arms in his chest, and finally the Gattilusi coats of arms. The inscription underneath the panels, dated to I423-4, identifies Dorino Gattilussio (1428-55) as the lord of Old Phocea. Dorino used the double-headed eagle with the Gattilusi coats of arms also in his coins. In an example from the British Museum coin collection, a copper coin from Dorino's rule shows a double-headed eagle with the insignia of the Gattilusi in his chest in the obverse and a cross with the four betas in the reverse (Fig. I5) (Schlumberger 1954, 444, pl. XVI, 30; for the appearance of the four betas in Byzantine and Gattilusian coins, see Androudis 2002, 27-30). The coin iconography is indicative of the Gattilusi self-representation. On the one 
hand, they are adopting a narrative of the Crusades and Western domination of the Eastern Mediterranean following a visual tradition known from the silver denier tournois circulating in Frankish Greece in the thirteenth century. On the other hand, they separate themselves from other Western lords, combining Gattilusi and Byzantine insignia and creating a hybrid visual language of identification and power (Grierson 1982, 283). This allows the Gattilusi to negotiate their authority and reinvent their identities and affiliations, while masking ethnic and religious differences between them and the ruled populations.

The development of a visual grammar that tied the Gattilusi rule with the Palaiologoi had to be complemented by an appealing political agenda and a robust building programme. The Gattilusi had to tackle the pragmatic needs of the territories under their rule, especially the need for safety, the maintenance of fortifications and the development of economic activities and maritime commerce. Their building programme was very similar to that of Alexios and John, and focused on fortifications in coastal areas and safe ports to stimulate sea commerce. They were very proactive in both repairing and rebuilding pre-existing castles and adding new fortifications to the areas they controlled. For example, Francesco I, immediately after receiving Mytilene, repaired the entire castle of Mytilene, respecting the course of pre-existing Byzantine walls and incorporating in his new walls Byzantine structures, as well as spolia from the ancient theatre (Loupou-Rokou 1999, I72; Acheilara 1999, I8-19). The castle was divided into two tiers (upper and middle) occupied by the Gattilusi and their administration, while the locals were living outside the main castle in a nearby quarter that was also fortified. The only remains from that period are the central inner line of walls and the church of St John, while everything else dates form the Ottoman period (Hasluck 1908, 259-65; Loupou-Rokou I999, I72-3; Acheilara I999, II; Georgopoulou-d'Amico 200I, 52-3).

On the island of Samothrace, another North Aegean island under Gattilusian control, two major fortifications at Chora and Palaiopolis and a coastal tower known as the tower of Phonias on the north side of the island are associated with their rule (Georgopoulou-d'Amico 200I, 58-9; Tsouris 2012, 573; Androudis 2013, 233-9). Samothrace was given to Palamedes

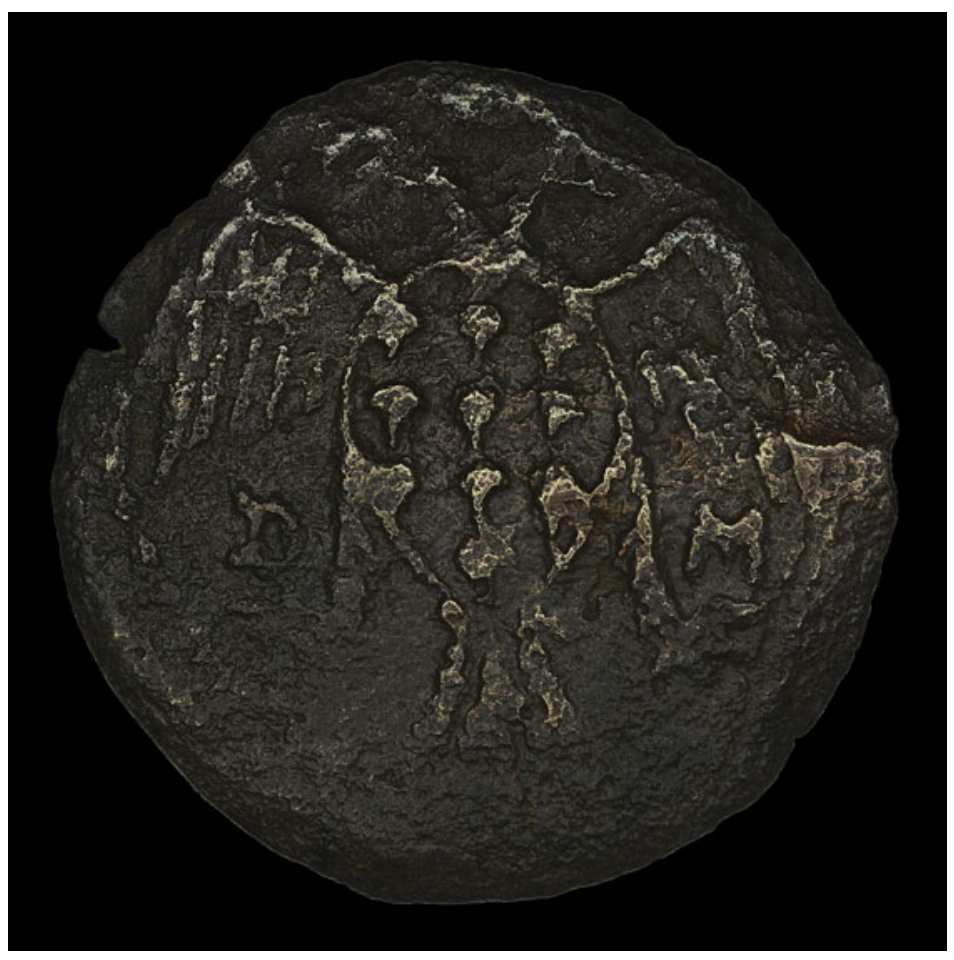

Fig. 15. Fifteenth-century alloy coin of Dorino Gattilusio, Lordship of Mytilene, British Museum (museum number I854,0818.38). Courtesy of the Trustees of the British Museum. 
Gattilusio at the beginning of the fifteenth century with the expectation that he would defend and protect it and govern in the name of the emperor; it is important to note that Palamedes was also related to the Palaiologoi directly, since his daughter was married to the Byzantine Emperor John VI, exemplifying again the role of intermarriages in the political management of the empire (Kiousopoulou 20II, 6I; Androudis 2013, 233). There are two interesting elements in Palamedes' fortifications. First, the rapid response to the need of fortification; based on inscriptions referring to the date of the fortifications' construction, the Gattilusi had significantly boosted the defence of the island in only three years (I43I-3) (Androudis 20I3, 238). Equally interesting are the numerous Greek and Latin inscriptions on the fortification walls addressing both locals and Genoese, and introducing Palamedes as the protector of the island and responsible for strengthening its defence (Androudis 2013, 235-6; for similar inscriptions in Greek in the fortifications at Ainos, see Hasluck 1908, 254).

After becoming rulers of Thasos (I4I9), the Gattilusi concentrated their efforts on maintaining and expanding the fortifications at Limenas to further serve their political and economic agendas. Besides their connection to the emperor, the Gattilusi were also following in the footsteps of Alexios and John and their successful government, thus also embedding their narrative within that of the island's recent past. At Limenas, the Gattilusi rebuilt the acropolis with strong walls and towers. At least the two square towers still standing in the acropolis circuit walls, the cisterns and a chapel in its interior, are probably associated with the Gattilusi rule (Fig. I6) (Dadaki and Giros I994, 387; Koder 1998, I82; Karagianni 2010, 133-4). The most prominent feature of the acropolis is its monumental gate that is entirely built with large blocks of spolia, matching the aesthetics and building material of the port fortifications, adding to the castle's monumentality (Fig. 17). According to Cyriacus of Ancona, the use of spolia also extended to the beautification of the port, with an array of marble statues along it (Bodnar and Mitchell 1976, 42-4). The Gattilusi's building activities at Thasos reflect their concerns about security, but also their interest in monumentality. Notions of wealth, control and monumentality travelled well in a more international commercial and political stage, since the Gattilusi wanted to reintroduce Thasos and the port of Limenas as an important hub in the sea trade between the West, Constantinople and the Black Sea. The imported pottery of the fifteenth century found at Limenas from the Black Sea, Spain and Italy represents the long-distance trade networks of Genoa in which the Gattilusi were involved; hence, it speaks to their successful strategies to connect Thasos' with wider commercial, cultural and political networks beyond Northern Aegean and the Byzantine Empire (François 1995, I25-30, I4I).

The Gattilusi's building activities, political propaganda and visual language underscore the ways in which they crafted their own local identities and negotiated their affiliations both with the local communities under their rule and with the Byzantine court. A shared sense of belonging and a strong connection to the local population facilitated their negotiation of authority, enhanced the economic and demographic stability in their ruling territories and promoted their own political and economic agendas.

\section{LATE BYZANTINE MODES OF RULESHIP AND FRONTIER CONTROL}

The stories of Alexios, John and the Gattilusi offer a different avenue of exploration pertaining to the changes in Late Byzantine mode of government and border administration, particularly in its last century, from the mid-fourteenth to the mid-fifteenth century. The choice of borderlords, their expanded roles in frontier areas and the nature of their authority derive from the political and economic realities of the Eastern Mediterranean in the fourteenth to fifteenth centuries, particularly the empire's limited resources, territorial loss and the rise of new economic and political powers around its borders. These borderlords are also associated with imperial policies in times of extreme political and military stress. John V's grants to Alexios, John and the Gattilusi coincided with the end of the civil wars, a time when both the empire's and traditional elites' resources were exhausted and Byzantine territories were in immediate need of protection. 


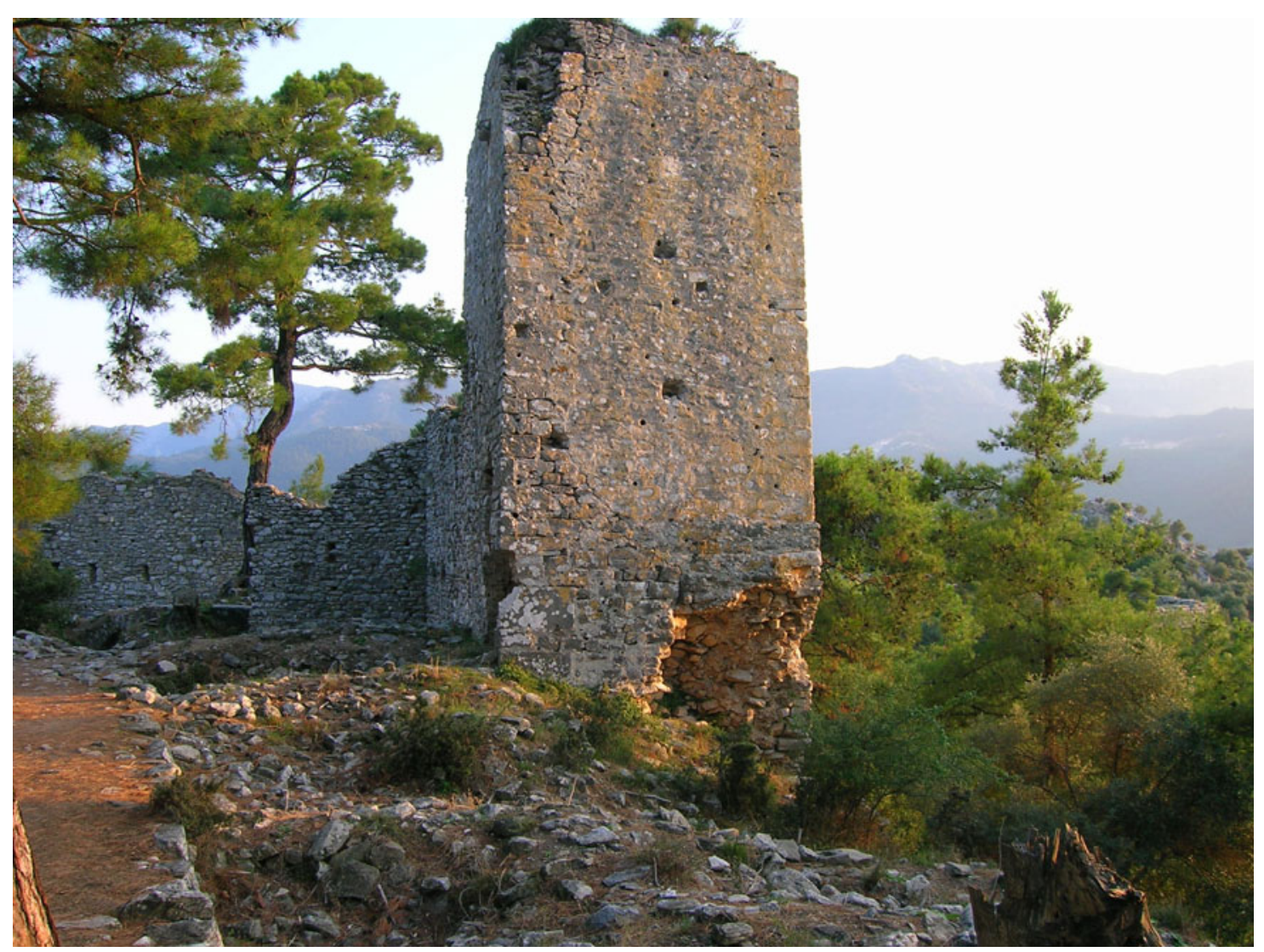

Fig. I6. Tower from the upper acropolis, Limenas, Thasos (photo by author).

Framed in a context of decline, John V's grants and rights bestowed upon these borderlords can be understood as proof of the political and economic deterioration of the Late Byzantine Empire. They support the idea that the Late Byzantine emperors were unsuccessful in ruling and protecting their territories and in resisting pressures from foreign and domestic elites. While I do not wish to underplay the severe political and economic challenges of the fourteenth and fifteenth centuries, Byzantine imperial policies can be better understood when seen within a framework of wider changes in the political landscape of the Eastern Mediterranean (see also Wright 2012). They should also be studied in relation to changes in the function of the imperial office in the last Byzantine century. In her excellent book about the Byzantine state and the political landscape of the fifteenth century, Tonia Kiousopoulou (201I, I3O-2) introduces the Late Byzantine emperors more as managers and administrators than as absolute rulers, who had to adapt to the political and economic realities of their time and were forced to allocate to individuals and groups tasks that were previously the state's responsibility. In the process, imperial rule became more inclusive of various social groups, such as the imperial family and the aristocratic circles, as well as the city council and even the local population, who would participate in imperial policies and decision-making in various degrees (Kiousopoulou 20II, 86-II4). A more fruitful way of considering the role of borderlords beyond a frame of decline would thus be to recognise an imperial ruling system that invited the participation of different agents, was more flexible in its mode of exercising control, and used an elaborate system of social and economic mechanisms to regulate its relation with all agents involved in political and military action.

As we saw earlier in this article, the imperial grant of lands and tax exemptions had been in the empire's ruling kit of the periphery for centuries, but the frequency of such grants in Late Byzantium is so startling that it introduces a new default modus operandi for running the empire (Magdalino 2002, 263-4; Bartusis 2013, 610-13). From the thirteenth century onwards, 


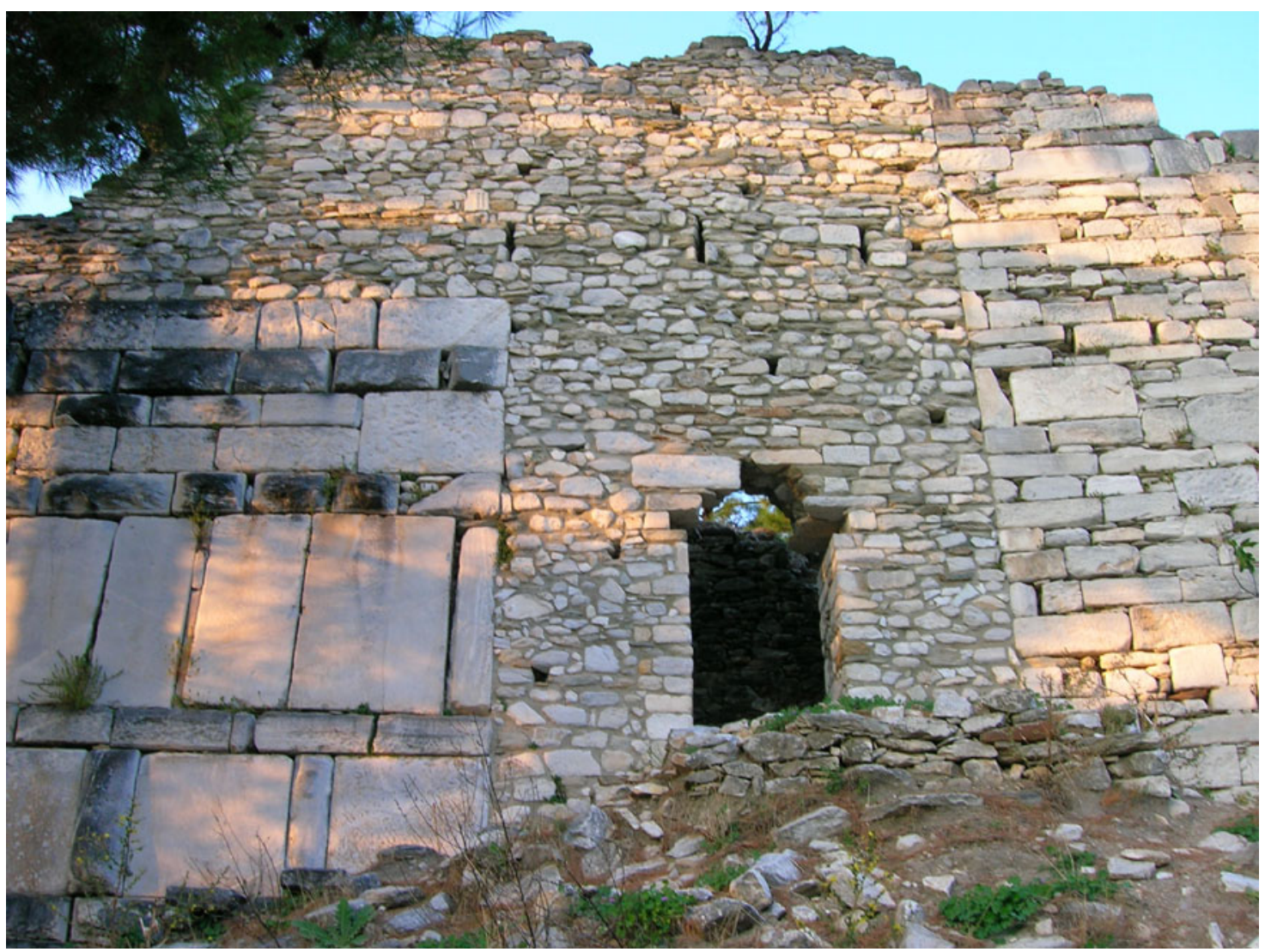

Fig. I7. The monumental gate of the upper acropolis with extensive ancient spolia at Limenas, Thasos (photo by author).

the number of these grants had significantly increased; they become hereditary and (as in the cases of Alexios and John, and the Gattilusi) they also came with full administrative and judicial authority (Haldon 2009, I88; Bartusis 2013, 274-82). Such grants weakened the state and deprived it of resources, and moreover reinforced the power and wealth of elite groups in the provinces, thus giving rise to new agents of power who supplanted imperial authority in the borders and only nominally adhered to the central administration (Laiou 1973, I47-9). Their power could pose a threat to imperial authority, since the elites' allegiance to the Byzantine emperor was only as strong as the benefits he could offer them at a given time (Standen 1999, 2I-2; Kazhdan and Wharton 1985, 64-5; Magdalino I993, 9-II; Zartman 2010, I4). Many were deeply rooted in frontier areas, with first-hand knowledge of the landscape and the people with large estates and properties, and could easily gain popularity with the locals and the army if they could successfully protect the frontiers, especially in times when the empire was failing to do so (Magdalino I984; Maksimović 1988, I23; Angold I984b, 237).

These grants can, however, also be understood as a balancing act that allowed the emperors to exploit and accommodate a range of different and often clashing interests (Angold 2013, 92). The competition for such grants and for favour and proximity to the emperor more generally was fierce, and provided emperors with the means of maintaining the loyalty and support of elites, managing the ambition and power struggles of antagonistic groups and regulating their access to resources and power (Frankopan 2009, II4-26; Haldon 2009, I8I; Stathakopoulos 2009, 96). This can clearly be seen from both the allocation and the confiscation of lands, which served as ways for emperors to manage power struggles and regulate society (Haldon 2009, I95; Bartusis 2013, 545-8). This balancing act extends to imperial efforts to keep frontier zones safe and within their sphere of influence without bearing the costs for their protection. Instead, borderlords were responsible for the costs of defence, such as repairs and new construction of fortifications, as 
well as any other investments in the frontier zones, such as ports. More importantly, at a time with no real imperial navy to speak of, these were groups which could provide the Late Byzantine emperors with a ready fleet that could patrol the coasts and islands and respond to the increased aggression of Turkish fleets (Wright 2012, 256-7).

The challenge of such political and military arrangements lay in the question of how best to maintain the loyalty of groups to the Byzantine emperor when they enjoyed such autonomy over their ruled territories. The imperial strategy pertaining to borderlords' effective rule and loyalty to the emperor was twofold, and related to strong bonds between borderlords and their ruled areas, and between borderlords and the emperor himself. By granting borderlords authority over specific areas, their population and revenues, Byzantine emperors created the right political and social conditions in which the lords' well-being was embedded in the frontier region's well-being (Stephenson 2000, 318; Neville 2004, II, 13, 28; Haldon 2009, I88). A lord, whose residence, fortune and sources of income were located in the areas he ruled, could prove more efficient than a slow, bureaucratic system of a large imperial government in collecting taxes and dealing with pressing matters, such as an enemy attack. In Alexios and John and Francesco Gattilusio, John $\mathrm{V}$ found men who could lead armies and fleets and invest in the protection of coastal areas. In both case studies, fortifications were a priority for the borderlords, who also undertook the expenses of defence. Seen in such a light, the imperial policy of granting power over Byzantine territories to these borderlords was a mechanism to boost the defences of the empire's borderlands at a time of scarce imperial finances and the lack of a fleet (Wright 2014, 85).

The other dimension of imperial policies involved marriage strategies between borderlords and the imperial family. As mentioned before, John was married to the emperor's cousin, and Francisco Gattilusio was given Mytilene as a dowry after marrying the emperor's sister. Marriage strategies were always central to Byzantium's relations with foreign powers. Already in the Komnenian period marriage strategies were responsible for extensive political alliances throughout southeastern Europe that rested on a close relationship to the Byzantine power, thus transforming power from state- to family-centred (Neville 20I2, IO4-II; Stankovic 20I5, 36-8). In Late Byzantium, however, marriage strategies became central both to foreign policies and to internal affairs, and the empire was ruled by the emperor and his oikeioi, members of his family and inner circle (Macrides 1992; Origone 1995). The imperial oikeioi were sanctioned by the emperor to exercise power, make decisions, enforce imperial decisions and represent the emperor in diplomatic missions, often without holding a title and an official position in the court (Kiousopoulou 20II, 82-5). Imperial titles thus became honorific, losing the prestige and exclusivity that had come with them in the previous centuries; primacy was given instead to familiarity with the emperor (Harris 2012, I22-3).

In the case of the borderlords discussed here, the personal connection with the Byzantine emperor was the source of their authority and wealth, forcing them to align their interests with those of the empire (Wright 20I2, 248). These familial ties also facilitated a better political integration of areas that were in the Byzantine sphere of influence but not under its direct control. The emphasis on the personal relationship with the emperor relied on the Byzantines' firm belief in the empire's prime role in the world and the supremacy of the Byzantine emperor as the most significant ruler of the known world. Despite the diminishing power of the Byzantines, this ideology still maintained its allure for domestic and foreign elites who wanted to be associated with the Byzantine Empire and partake of its authority.

These socio-economic mechanisms employed by Late Byzantine emperors in protecting the borders and maintaining control over frontier territories point to indirect forms of domination and control. Alconini (2008, 65, table 6I) has described this as a form of hegemonic control in which the central power prefers a low-investment/low-extractions strategy and delegates political control in frontier zones to elites stationed in those areas. The success of this model of control is dependent upon the creation of networks between the capital and these frontier zones and includes patron-client relations, as well as alliances through marriages and the formation of common interests, such as the defence against external threats (Alconini 2008, 65, 79). Alconini developed this framework for her research on the control of frontier zones and the incorporation of native local groups in the Inca empire; however, the idea of indirect control of contested areas 
and frontiers is relevant to the political and economic strategies of other ancient and medieval states (for other examples of indirect imperial control in border zones, see Parker 2006, 84).

Evidence of indirect control as a preferred mode of government can already be traced in the Komnenian period when John Komnenos planned to marry his son Manuel to the young heiress of Antioch and establish him as an independent ruler of a region that included Antioch, Cilicia, Cyprus and Attaleia (Magdalino 2002, 36-4I). The solution of an independently ruled Antioch highlights a low-investment/low-yield approach which would appease other Latin ruling families competing for the control of Antioch while still bringing that region under Byzantine influence even in an indirect way. Furthermore, indirect control over that area would help the Byzantines restore their control in the East and protect their southern and eastern borders.

A model of low-investment/low-yield management resonates well with Late Byzantine strategies of border protection. The Byzantine state adopted a low-investment management of the border zones and allocated the responsibilities for their protection to powerful and wealthy individuals. Power became more decentralised, and the Byzantine emperor was transformed from an absolute ruler to a manager who allocated tasks and traded lands and grants for military and financial support. In sensitive areas, such as the coasts and islands, he replaced central imperial authority with a network of ruling elites who assumed the emperor's role in the frontier, thus creating more local-based forms of government. Despite the lack of economic obligation towards the empire, the Byzantine emperors' expectation was that they could always extract some benefit and that at least in extreme situations, such as famine or an attack upon Constantinople, these frontier lords would come to the rescue (Wright 2014, 85). In any case, the ties to Constantinople were maintained mainly at a cultural, ideological and symbolic level rather than at an economic and administrational one.

This style of political management was informed also by Byzantium's relationship to its neighbours and competing powers. Late Byzantine emperors utilised strategies that Byzantines had employed for centuries with some of their Christian neighbours, abandoning the unrealistic role of all-powerful overlords, and adopting more realistic policies that included folding these rulers within the imperial household (Stankovic 2015, 42-5). At the same time, in the Late Byzantine period there is a distinct emphasis on the role of emperors not only as rulers of the Byzantine Empire but of the entire Christian oikoumene which extended beyond the territorial and political control of Byzantium (Shepard 2006, I8-I9; Kyriakidis 20II, 2I; Wright 20I2, 248). Regardless of whether such a world order was accepted by or palatable to others, what is important is to recognise how such a vision helped the Byzantines navigate the political complexities and use this rhetoric as a vehicle for political propaganda that helped them adjust their role to the new world order (see also Hilsdale 2014, 327-32 on Late Byzantine diplomatic gifts and the idea of oikoumene). This ideology allowed more flexibility in the way that Byzantine imperial authority could be imagined and articulated at a time of significant territorial losses and political fragmentation. That kind of rhetoric aligns well with this model of low investment/low yield because it allowed Late Byzantine emperors to bring under their sphere of influence different regions, groups and individuals, even when they had only nominal control over them. Within that low-investment/low-yield mode of management, borderlords contributed to a decentralised Byzantine Empire but ultimately aligned their interests with those of the Late Byzantine emperors in order to create a safe and amicably ruled buffer zone around the Aegean and around Constantinople.

\section{CONCLUSIONS}

In this paper I have addressed issues of authority negotiation in Late Byzantine frontier zones, focusing on borderlords and their political and economic strategies. Emphasis was placed on their building programmes and defensive structures as well as the visual language employed by borderlords to articulate their identities and negotiate their role and authority in the regions under their rule. The examples of Alexios, John and the Gattilusi speak to their multiple 
identities and agendas, actions and social networks that affected and defined life in the borders. On the one hand, there is the paradox of John, a Byzantine military official with Venetian citizenship, who assumed the role of the Byzantine state in coastal Macedonia and Thasos and replaced it in its borders. In establishing his authority, he emphasised his rank and wealth and patronage. When it came to his relation to the Byzantine emperor he was ready to adjust his message and emphasise or underplay his connection to central administration according to the audience. On the other hand, the Genoese family of Gattilusi adopted many Byzantine symbols of authority and put great emphasis on their ties with the Palaiologoi to establish their control. The stories of those families suggest that cooperation, loyalty and social ties to the imperial court could coexist and were not mutually exclusive with the borderlords' own political agendas. They also highlight changes in Byzantine government and in the role of Late Byzantine emperors, who adopted more realistic policies, experimented with different ways of responding to severe political and economic challenges and became more flexible and inclusive of other groups in the protection and management of the empire and its frontier zones.

\section{ACKNOWLEDGEMENTS}

The ideas in this article were first presented in a session entitled 'Power at the Limits of Authority' at the 77th Annual Meeting of the Society for American Archaeology in April 2012. I am grateful to the session organisers Andrew Scherer and Charles Golden for their invitation to participate and for our great conversation on Maya/Byzantine borders and borderlords. I would also like to thank the Director and colleagues at the Ephorate of Antiquities at Kavala-Thasos for their cooperation while I was conducting my field work on Thasos and the Ephorate of Antiquities at Serres for collaboration. I am also indebted to Christopher Wright, who very kindly allowed me to read his $\mathrm{PhD}$ on the Gattilusi before his book was out. Many thanks are also due to Paschalis Androudis for his generosity and collegiality and for the information and images he provided me with for the purposes of this article. I am also grateful to the anonymous reviewers for their valuable comments and suggestions to improve the quality of the paper. Finally, I owe great thanks to my parents, who walked with me and climbed many of the fortifications mentioned in this article on Thasos and Macedonia.

fk8u@virginia.edu

\section{REFERENCES}

Acheilara, L. I999. The Kastro of Mytilene (Athens).

Alconini, S. 2008. 'Dis-embedded centers and architecture of power in the fringes of the Inka Empire: new perspectives on territorial and hegemonic strategies of domination', fAnthArch $27,63-81$.

Anagnostakis, I. 2015. "“From Tempe to Sparta": power and contestation prior to the Latin Conquest of I204', in Simpson, A. (ed.), Byzantium, II80-I204: 'The Sad Quarter of a Century'? (Athens), 135-57.

Androudis, P. 2002. 'Sur quelques emblèmes héraldiques à Constantinople (xiiie-xve siècles)',

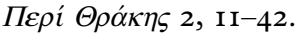

Androudis, P. 2013. 'Deux fortifications des Gattilusi à Samothrace: chôra et palaiapolis', in Karagianni, F. (ed.), Medieval Ports in North Aegean and the Black Sea. Links to the Maritime Routes of the East (Thessaloniki), 233-47.

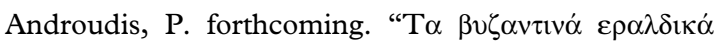

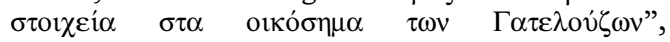

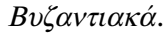

Angold, M. I984a. 'Introduction', in Angold, M., The Byzantine Aristocracy, IXth to XIIIth Centuries (Oxford), I-9.

Angold, M. I984b. 'Archons and Dynasts: local aristocracies and the cities of the later Byzantine Empire', in Angold, M. (ed.), The Byzantine Aristocracy, IXth to XIIIth Centuries (Oxford), 236-53.

Angold, M. I999. 'The Road to I204: the Byzantine background to the Fourth Crusade', Fournal of Medieval History 25, 257-78.

Angold, M. 2003. The Fourth Crusade: Event and Context (Harlow; New York).

Angold, M. 20I2. 'Michael VIII Palaiologos and the Aegean', in Saint-Guillain, G. and 
Stathakopoulos, D. (eds), Liquid and Multiple: Individuals and Identities in the Thirteenth-Century Aegean (Paris), 27-44.

Angold, M. 20I3. 'The political arts at the late Palaiologan court (I402-I453)', in Angelov, D. and Saxby, M. (eds), Power and Subversion in Byzantium. Papers from the 43rd Spring Symposium of Byzantine Studies, Birmingham, March 2010 (Farnham; Burlington), 83-IO4.

Bartusis, M. I992. The Late Byzantine Army. Arms and society, I204-I453 (Philadelphia).

Bartusis, M. 2013. Land and Privilege in Byzantium: The Institution of Pronoia (Cambridge).

Baud, M. and Schendel, W. van 1997. 'Toward a comparative history of borderlands', Fournal of World History 8, 2 I I-42.

Bellinger, A.R. and Grierson, P. 1999. Catalogue of the Byzantine Coins in the Dumbarton Oaks Collection: Michael VIII to Constantine XI, I258-I453 (Washington, D.C.).

Berend, N. I999. 'Medievalists and the notion of the frontier', The Medieval History fournal 2, 55-72.

Bodnar, E.W. and Mitchell, C. 1976 Cyriacus of Ancona's fourneys in the Propontis and the Northern Aegean, I444-I445 (Philadelphia).

Bourdieu, P. I994. 'Structures, Habitus, Power: basis for a theory of symbolic power', in Dirks, N.B., Eley, G. and Ortner, S.B. (eds), Culture/Power/ History: A Reader in Contemporary Social Theory (Princeton, N.J.), I55-99.

Carr, A.W. 2006. 'Donors in the frames of icons: living in the borders of Byzantine art', Gesta 45:2, I89-98.

Carr, M. 20I4. 'Trade or Crusade? The Zaccaria of Chios and Crusades against the Turks', in Chrissis, N.G. and Carr, M. (eds), Contact and Conflict in Frankish Greece and the Aegean, I2041453: Crusade, Religion and Trade between Latins, Greeks and Turks (Farnham), II5-34.

Cheynet, J.-C. I990. Pouvoir et contestations à Byzance (963-I210) (Paris).

Cheynet, J.-C. 2006. 'The Byzantine aristocracy (8thI3th centuries)', in Cheynet, J.-C. (ed.), The Byzantine Aristocracy and its Military Function (Aldershot), I-43.

Chrissis, N.G. and Carr, M. 20I4. 'Introduction', in Chrissis, N.G. and Carr, M. (eds), Contact and Conflict in Frankish Greece and the Aegean, I204I453: Crusade, Religion and Trade between Latins, Greeks and Turks (Farnham), I-I6.

Crow, J. 2013. 'Fortifications and the Late Roman East: from urban walls to long walls', in Sarantis, A. and Christie, N. (eds), War and Warfare in Late Antiquity: Current Perspectives (Leiden), 397-432.

Dadaki, S., Doukata, S., Eliadis, I. and Lychounas, M.

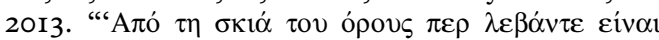

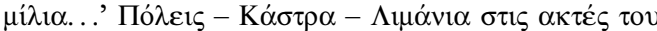

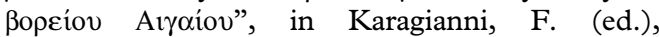
Medieval Ports in North Aegean and the Black Sea. Links to the Maritime Routes of the East (Thessaloniki), 2II-32.

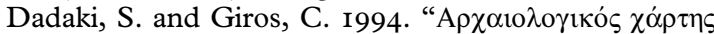

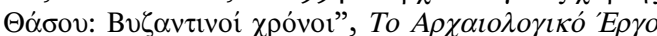

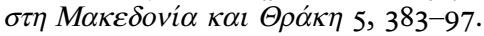

Dunn, A. I999. 'From polis to kastron in Southern Macedonia: Amphipolis, Chrysoupolis and the Strymon Delta', in André, B. (ed.), Castrum 5: Archéologie Des Espaces Agraires Méditerranéens Au Moyen Age (Madrid), 399-4I3.
Elizbarashvili, E. 2010. 'The formation of a hero in Digenis Akrites', GRBS 50, 437-60.

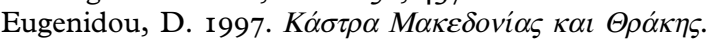
$B v \zeta \alpha v \tau \imath v \dot{~ K \alpha \sigma \tau \rho o \kappa \tau \iota \sigma i \alpha ~(A t h e n s) . ~}$

Failler, A. (ed.) I984-2000. Georges Pachymeres relations historiques, 5 vols. (Paris).

Falkenhausen, V. von I984. 'A provincial aristocracy: the Byzantine provinces in Southern Italy (9thIIth Century)', in Angold, M. (ed.), The Byzantine Aristocracy, IX to XIII Centuries (Oxford), 2I I-35.

François, V. 1995. La Céramique Byzantine À Thasos (Paris).

Frankopan, P. 2009. 'Land and power in the middle and late period', in Haldon, J. (ed.), A Social History of Byzantium (Oxford), I I 2-42.

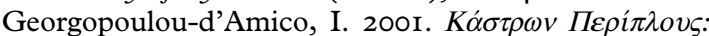
Castrorum Circumnavigatio (Athens).

Giros, C. I99I. 'Note sur la Fortresse du Port de Thasos', in Kravari, V. (ed.), Actes Du Pantokrator (Paris), 45-50.

Giros, C. and Dadaki, S. 200I. 'Peuplement et défense du littoral de Thasos au moyen âge', in Martin, J-M. (ed.), Castrum 7: zones côtières littorales dans le monde méditerranéen au moyen âge (Rome), 5I3-I9.

Grandjean, Y. and Salviat, F. 2000. Guide De Thasos (Athens; Paris).

Grierson, P. 1982. Byzantine Coins (London; Berkeley).

Haldon, J. 1999. Warfare, State, and Society in the Byzantine World, 565-I204 (London).

Haldon, J. 2009. 'Social elites, wealth and power', in Haldon, J. (ed.), A Social History of Byzantium (Oxford), I68-2II.

Harris, J. 20I2. 'Constantinople as city-state, c.I360I453', in Harris, J., Holmes, C. and Russell, E. (eds), Byzantines, Latins and Turks in the Eastern Mediterranean World after II5O (Oxford), II9-40.

Hasluck, F.W. I908. 'Monuments of the Gattelusi', $B S A$ I 5, 248-69.

Hilsdale, C.J. 2014. Byzantine Art and Diplomacy in an Age of Decline (Cambridge).

Holtzmann, B. I979. 'Thasos', $B C H$ I03, 635-4I.

Hull, D.B. 1972. Digenis Akritas, the Two-Blood Border Lord (Athens; Ohio).

Jeffreys, E. I980. 'The Comnenian background to the romans d'antiquité', Byzantion 50, 478-8I.

Kaegi, W.E. I996. 'Reconceptualizing Byzantium's eastern frontiers in the seventh century', in Mathisen, R.W. and Sivan, H.S. (eds), Shifting Frontiers in Late Antiquity (Aldershot), 83-92.

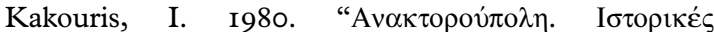

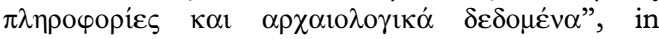

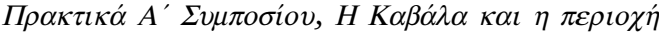
$\tau \eta \varsigma$ (Thessaloniki), 249-62.

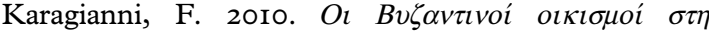

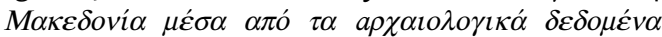
(Thessaloniki).

Kazhdan, A.P. and Wharton, A.J. 1985. Change in Byzantine Culture in the Eleventh and Twelfth Centuries (Berkeley).

Kiousopoulou, T. 20II. Emperor or Manager: Power and Political Ideology in Byzantium before 1453 (Geneva).

Koder, J. 1998. Aigaion Pelagos. Die Nördliche Ägäis (Vienna).

Kondyli, F. 20I0. 'Tracing monastic economic interests and their impact on the rural landscape of Late Byzantine Lemnos', DOP 64, I29-50. 
Kondyli, F. 2016. 'Against crisis: the role of the monastic estates of Mount Athos in Late Byzantium', in

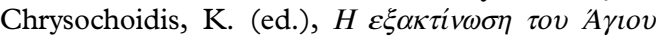

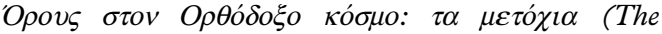
Expansion of Mount Athos in the Orthodox World: The Monastic Estates), (Thessaloniki), 6I-7I.

Kravari, V. I99I. Actes Du Pantocrator (Paris).

Kulikowski, M. 2005. 'Ethnicity, rulership, and early medieval frontiers', in Curta, F. (ed.), Borders, Barriers, and Ethnogenesis: Frontiers in Late Antiquity and the Middle Ages (Turnhout).

Kutchen, L. 2005. 'The Neo-Turnerian Frontier', Early American Literature 40, I63-7I.

Kyriakidis, S. 20II. Warfare in Late Byzantium, I204I453 (Leiden).

Laiou, A.E. I973. 'The Byzantine aristocracy in the Palaeologan period: a story of arrested development', Viator 4, I3I-52.

Laiou, A.E. 2005. Urbs capta: the Fourth Crusade and its Consequences (Paris).

Laiou, A.E. 2008. 'The Palaiologoi and the world around them (I26I-I400)', in Shepard, J. (ed.), The Cambridge History of the Byzantine Empire c. 500-I492 (Cambridge), 803-33.

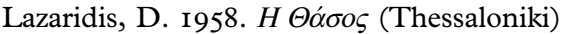

Lilie, R.J. 2005. 'The Byzantine-Arab borderland from the seventh to the ninth century', in Curta, F. (ed.), Borders, Barriers and Ethnogenesis. Frontiers in Late Antiquity and the Middle Ages (Turnhout), I3-2 I.

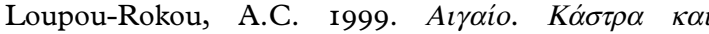
$K \alpha \sigma \tau \varepsilon^{\prime} \lambda \lambda \iota \alpha$ (Athens).

Lunardi, G. I980. Le Monete Della Colonie Genovesi (Genoa).

Macrides, R. I992, 'Dynastic marriages and political kinship', in Shepard, J. and Franklin, S. (eds), Byzantine Diplomacy: Papers of the Twenty-Fourth Spring Symposium of Byzantine Studies, Cambridge, March 1990 (Aldershot), 263-80.

Macrides, R., Munitiz, J.A. and Angelov, D. 2013. Pseudo-Kodinos and the Constantinopolitan Court: Offices and Ceremonies (Farnham).

Magdalino, P. I984. 'The Byzantine aristocratic oikos', in Angold, M. (ed.), The Byzantine Aristocracy, IX to XIII Centuries (Oxford), 92-III.

Magdalino, P. I993. 'Digenis Akrites and Byzantine literature: the twelfth-century background to the Grottaferrata version', in Beaton, R. and Ricks, D. (eds), Digenis Akrites: New Approaches to Byzantine Heroic Poetry (Aldershot), I-I4.

Magdalino, P. 2002. The Empire of Manuel I Komnenos, II43-II8O (Cambridge).

Maksimović, L. I988. The Byzantine Provincial Administration under the Palaiologoi (Amsterdam).

Mallouchou, F. and Tufano, S. I980. "Н Акро́ $\pi$ о $\eta \eta \tau$

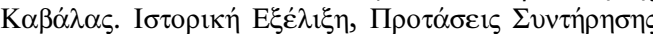

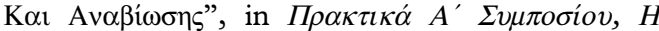

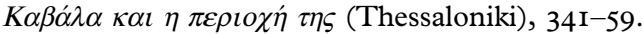

Miller, W. I9I I. 'The Zaccaria of Phocaea and Chios', $7 H S_{31}, 42-55$.

Mulliez, D., Muller, A. and Blondé, F. 2000. 'Thasos', $B C H$ I24, 506-2I.

Naum, M. 20IO. 'Re-emerging frontiers: postcolonial theory and historical archaeology of the borderlands', Fournal of Archaeological Method and Theory I7, IOI-3I.

Necipoğlu, N. 2009. Byzantium between the Ottomans and the Latins: Politics and Society in the Late Empire (Cambridge).
Neville, L. 2004. Authority in Byzantine Provincial Society, 950-IIOO (Cambridge).

Neville, L. 2012. Heroes and Romans in Twelfth-Century Byzantium: The Material for History of Nikephoros Bryennios (Cambridge).

Nicol, D.M. 1993. The Last Centuries of Byzantium, I26I-I453 (Cambridge).

Oikonomides, N. 1996. 'Patronage in Palaiologan Mt Athos', in Bryer, A. and Cunningham, M. (eds), Mount Athos and Byzantine Monasticism: Papers from the Twenty-Eighth Spring Symposium of Byzantine Studies, Birmingham, March 1994 (Aldershot), 99-II2.

Origone, S. I995. 'Marriage connections between Byzantium and the West in the age of the Palaiologoi', Mediterranean Historical Review Io, 226-4I.

Ousterhout, R. 2013. 'Emblems of power in Palaiologan Constantinople', in Ödekan, A., Necipoğlu, N. and Akyürek, E. (eds), The Byzantine Court: Source of Power and Culture: Papers from the Second International Sevgi Gönül Byzantine Studies (Istanbul).

Parani, M. 2003. Reconstructing the Reality of Images: Byzantine Material Culture and Religious Iconography IIth-I5th Centuries (Leiden; Boston).

Parani, M. 2007. 'Cultural identity and dress: the case of Late Byzantine ceremonial costume', $\mathcal{F O ̈ B ~ 5 7 , ~}$ 95-I34.

Parker, B.J. 2006. 'Toward an understanding of borderland processes', AmerAnt 71, 77-100.

Pavlikianov, C. 2001. The Medieval Aristocracy on Mount Athos (Sofia).

Pohl, W. 2005. 'Frontiers and ethnic identities: some final considerations', in Curta, F. (ed.), Borders, Barriers, and Ethnogenesis: Frontiers in Late Antiquity and the Middle Ages (Turnhout), 255-65.

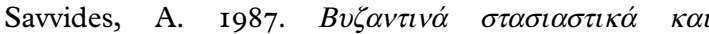

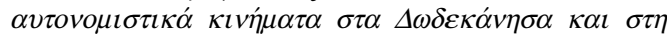

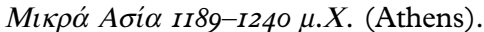

Schlumberger, G.L. I954. Numismatique De L'orient Latin (Graz).

Schopenus, L. (ed.) 1828-32. Ioannis Cantacuzeni eximperatoris historiarum Libri IV, 3 vols (Bonn).

Sevcenko, N.P. I993. 'The representation of donors and holy figures on four Byzantine icons', Deltion Christianikes Archaeologikes Hetaireias 35, I57-64.

Shepard, J. 2006. 'Byzantium's overlapping circles', in Jeffreys, E. (ed.), Proceedings of the 2Ist International Congress of Byzantine Studies, London 2I-26 August, 2006 (Aldershot), I5-55.

Slotkin, R. 1992. Gunfighter Nation: The Myth of the Frontier in Twentieth-Century America (New York).

Smith, A. 2003. The Political Landscape. Constellations of Authority in Early Complex Societies (Berkeley).

Smith, M.L. 2005. 'Networks, territories, and the cartography of ancient states', Annals of the Association of American Geographers 95, 832-49.

Spieser, J.-M. I973. 'La forteresse byzantine du port de Thasos: rapports de fouilles', $B C H$ 97, 54I-8.

Standen, N. I999. 'Nine case studies of premodern frontiers', in Power, D. and Standen, N. (eds), Frontiers in Question: Eurasian Borderlands, 700I700 (London), 13-32.

Stankovic, V. 2015. 'Stronger than it appears? Byzantium and its European hinterland after the death of Manuel I Komnenos', in Simpson, A.J. 
(ed.), Byzantium, II80-I204: 'The Sad Quarter of a Century'? (Athens), 35-48.

Stathakopoulos, D. 2009. 'The dialectics of expansion and retraction: recent scholarship on the Palaiologan aristocracy', Byzantine and Modern Greek Studies 33:I, 92-IOI.

Stein, M.L. 2007. Guarding the Frontier: Ottoman Border Forts and Garrisons in Europe (London).

Stephenson, P. I999. 'The Byzantine frontier at the lower Danube in the late tenth and eleventh centuries', in Power, D. and Standen, N. (eds), Frontiers in Question: Eurasian Borderlands, 700I700 (New York), 80-I04.

Stephenson, P. 2000. Byzantium's Balkan Frontier: A Political Study of the Northern Balkans, 900-I204 (Cambridge).

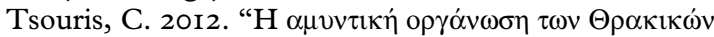

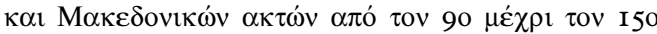
$\alpha \iota \omega ́ v \alpha "$, in Kavvadia, A. and Damulos, P. (eds), $H$

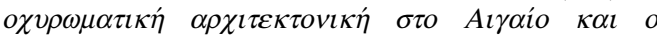

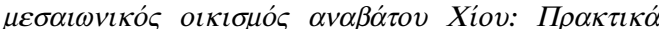

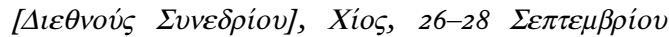
2008 (Chios), 56I-88.

Turner, F.J. 1963. The Significance of the Frontier in American History (New York).

Wilson, T.M. and Donnan, H. 1998. Border Identities: Nation and State at International Frontiers (Cambridge).

Wright, C. 20I2. 'Byzantine authority and Latin rule in the Gattilusio Lordships', in Harris, J., Holmes, C. and Russell, E. (eds), Byzantines, Latins, and Turks in the Eastern Mediterranean World after 1150 (Oxford), 247-63.

Wright, C. 20I4. The Gattilusio Lordships and the Aegean World 1355-I462 (Leiden; Boston).

Zartman, W. 20I0. 'Introduction. Identity, movement and response', in Zartman, W. (ed.), Understanding Life in the Borderlands: Boundaries in Depth and in Motion (Athens, Georgia), I-20.

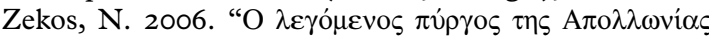

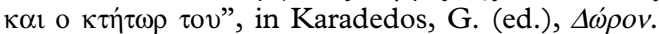

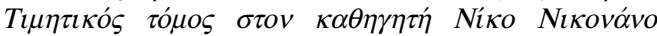
(Thessaloniki), 57-67.

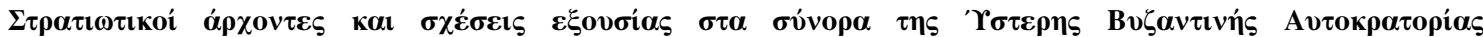 $\left(14{ }^{0 \varsigma}-15^{\text {os }} \alpha 1.\right)$}

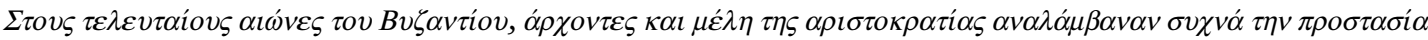

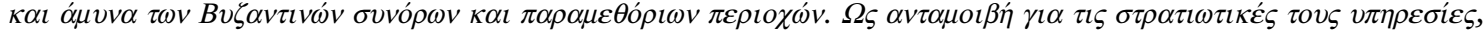

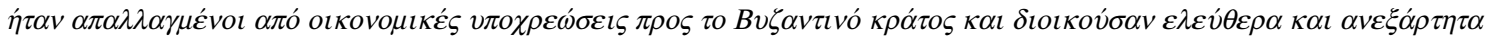

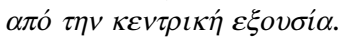

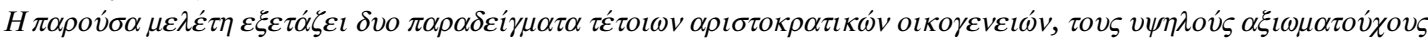

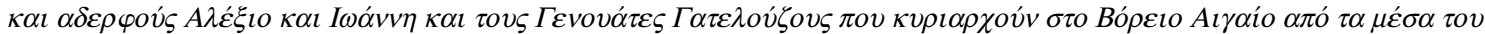

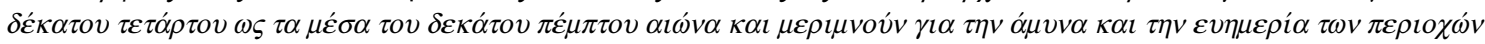

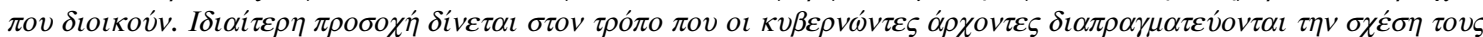

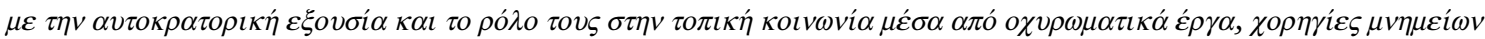

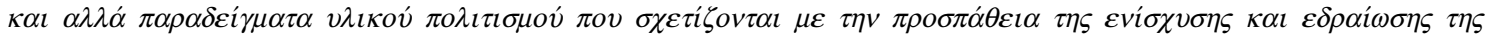

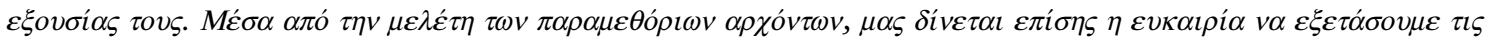

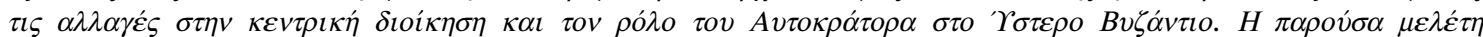

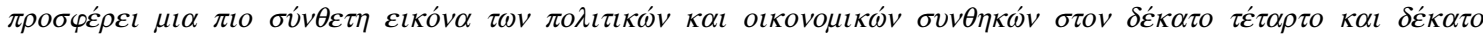

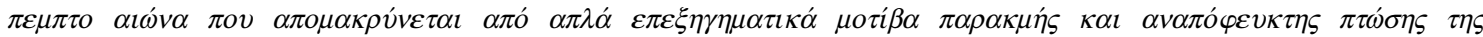
$B v \zeta \alpha v \tau \imath v \dot{\zeta} \varsigma \alpha v \tau о \kappa \rho \alpha \tau о \rho i \alpha \varsigma$. 